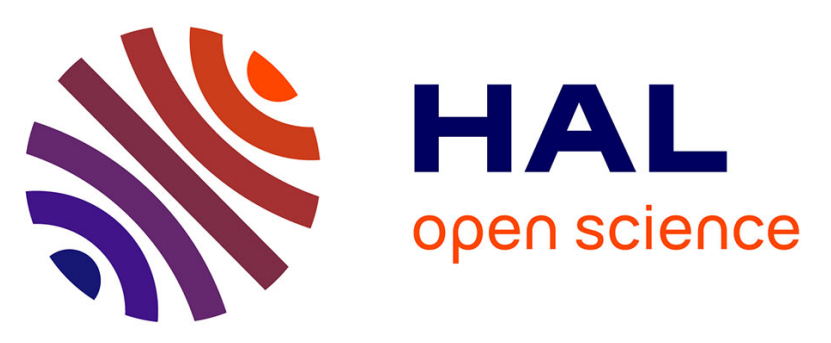

\title{
Reactivity of Lanthanoid Mono-Cations with Ammonia: a Combined Inductively Coupled Plasma Mass Spectrometry and Computational Investigation
}

Alexandre Quemet, Pierre Vitorge, Alvaro Cimas, Shengsi Liu, Jean-Yves

Salpin, Colin J. Marsden, Jeanine Tortajada, Laura Gagliardi, Riccardo Spezia, Marie-Pierre Gaigeot, et al.

\section{To cite this version:}

Alexandre Quemet, Pierre Vitorge, Alvaro Cimas, Shengsi Liu, Jean-Yves Salpin, et al.. Reactivity of Lanthanoid Mono-Cations with Ammonia: a Combined Inductively Coupled Plasma Mass Spectrometry and Computational Investigation. International Journal of Mass Spectrometry, 2013, 334, pp.27-37. 10.1016/j.ijms.2012.10.005 . hal-00796104

\section{HAL Id: hal-00796104 https://hal.science/hal-00796104}

Submitted on 3 Oct 2018

HAL is a multi-disciplinary open access archive for the deposit and dissemination of scientific research documents, whether they are published or not. The documents may come from teaching and research institutions in France or abroad, or from public or private research centers.
L'archive ouverte pluridisciplinaire HAL, est destinée au dépôt et à la diffusion de documents scientifiques de niveau recherche, publiés ou non, émanant des établissements d'enseignement et de recherche français ou étrangers, des laboratoires publics ou privés. 


\section{Reactivity of Lanthanoid Mono-Cations with Ammonia:}

\section{a Combined Inductively Coupled Plasma Mass}

\section{Spectrometry, and Computational Investigation.}

Alexandre Quemet, ${ }^{a}$ Pierre Vitorge, ${ }^{b, c}$ Alvaro Cimas, ${ }^{d}$ Shengsi Liu, ${ }^{e}$ Jean-Yves Salpin, ${ }^{c, f}$ Colin Marsden, ${ }^{g, h}$ Jeanine Tortajada, ${ }^{c, f}$ Laura Gagliardi, ${ }^{e}$ Riccardo Spezia, ${ }^{c, f}$ Marie-Pierre Gaigeot, ${ }^{c, f}$ René Brennetot ${ }^{*}, a$

${ }^{\text {a }}$ Laboratoire d'Analyse en Soutien aux Exploitants, CEA, DEN, DPC, SEARS, Saclay F-91991 Gif-surYvette, France

${ }^{\mathrm{b}}$ Laboratoire de Radiolyse et de la Matière Organique, CEA, DEN, DPC, SECR, Saclay F-91991 Gifsur-Yvette, France

${ }^{\mathrm{c}}$ CNRS UMR 8587.

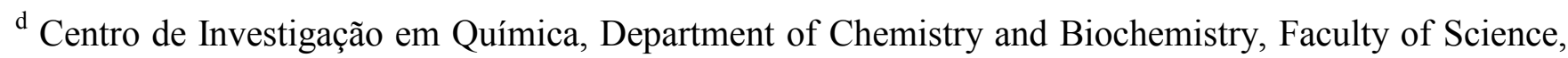
University of Porto, Rua do Campo Alegre, 687, P-4169-007 Porto, Portugal

${ }^{\mathrm{e}}$ Department of Chemistry, Superconducting Institute, and Center for Metals in Biocatalysis, University of Minnesota, 207 Pleasant Street SE, Minneapolis, Minnesota 55455-0431, United States

f Université d'Evry Val d'Essonne, Laboratoire Analyse et Modélisation pour la Biologie et l'Environnement, Boulevard F. Mitterrand, 91025 Evry Cedex, France

g Université Paul Sabatier - Laboratoire de Physique Quantique, 118 route de Narbonne, F-31062 Toulouse cedex 4, France

${ }^{\mathrm{h}}$ CNRS-UMR 5626.

*Corresponding author: rene.brennetot@cea.fr 


\begin{abstract}
The reactivity of $\mathrm{La}^{+}, \mathrm{Sm}^{+}, \mathrm{Eu}^{+}$and $\mathrm{Gd}^{+}$with $\mathrm{NH}_{3}(\mathrm{~g})$ and $\mathrm{ND}_{3}(\mathrm{~g})$ is studied in the reaction cell of a quadrupole ICP-MS. For $\mathrm{Ln}^{+}=\mathrm{La}^{+}$and $\mathrm{Gd}^{+}$, the primary reaction channel is the formation of the $\mathrm{LnNH}^{+}$ protonated nitride leading to $\mathrm{H}_{2}$ elimination. The $\mathrm{LnNH}\left(\mathrm{NH}_{3}\right)^{+}{ }_{1-5}$ ammonia complexes of the Ln protonated nitride are further generated $\mathrm{Sm}^{+}$and $\mathrm{Eu}^{+}$are much less reactive: the protonated nitride is not detected, and only small amounts of $\mathrm{Ln}\left(\mathrm{NH}_{3}\right)_{0-6}^{+}$are observed. DFT, MP2, CCSD(T) and CASSCF/CASPT2 calculations are used to explore the potential energy surfaces. For the $\mathrm{La}^{+}$and $\mathrm{Gd}^{+}$ ions of f-block elements, the reaction pathways have three steps: first the formation of $\mathrm{LnNH}_{3}^{+}$, then the isomerization to $\mathrm{HLnNH}_{2}{ }^{+}$, and finally the loss of $\mathrm{H}_{2}$ associated with the formation of a Ln-N triple bond in the final product $\mathrm{LnNH}^{+}$. On the other hand, $\mathrm{Sm}^{+}$and $\mathrm{Eu}^{+}$are not able to form stable complexes. This was rationalized in terms of energy barriers for the chemical reactions and electronic promotion energies for these $\mathrm{Ln}^{+}$atoms.
\end{abstract}

KEYWORDS : Ab initio, DFT, ICP-MS, Insertion reaction, Ion-molecule reactions, Lanthanides

\title{
1. Introduction
}

There is a renewed interest in the lanthanoid $(\mathrm{Ln})$ isotopic compositions of irradiated nuclear fuels for neutronic calculations of new nuclear reactors, and for the management of radioactive wastes. ${ }^{1-3}$ In both cases predictive modeling is based on nuclear data that are validated by isotopic analysis. For this, Inductively Coupled Plasma - Mass Spectrometry (ICP-MS) is currently the technique mostly used. It is a versatile tool having good detection limit for many elements and short time analysis. While this technique is used in several fields, ${ }^{4}$ isobaric interferences arise between different chemical elements with isotopes of equal mass, typically ${ }^{151,152} \mathrm{Sm} / \mathrm{Eu},{ }^{154} \mathrm{Sm} / \mathrm{Gd},{ }^{154,155} \mathrm{Eu} / \mathrm{Gd}$ in the nuclear fuel cycle, ${ }^{5}$ thus potentially causing some problems when this technique is used for the separation of lanthanoids. 
Using a collision/reaction cell is an elegant way to eliminate isobaric interferences, especially for heavy and radioactive isotopes. To that end, the cell (placed just before the mass filter) is filled with a low pressure gas chosen for its chemical reactivity and selectivity towards the interfering ions. ${ }^{4,6-8}$ Using an ICP-MS equipped with a collision/reaction cell, we intend to investigate the chemical reactivity of Lanthanoids with gases in order to provide a way of eliminating isobaric interferences and get an efficient method applicable for the separation of lanthanoids in the gas phase. More generally, we are interested in measuring the isotopic compositions of Ln fission products, ${ }^{9}$ actinoids (An) activation products and their decay products irradiated in nuclear fuels. ${ }^{10}$ Our experiments are performed with a commercially available Q-ICP-MS, where the ions are not especially thermalized prior to the reaction. This is different from the thermalized SIFT-MS ${ }^{5,11-15}$ experimental set-up developed by Bohme and coworkers, and one can imagine that the corresponding extra energy in our experimental set-up might induce different chemical reactions, in particular allowing more endothermic reactions. Only single mono-ionizations of lanthanoids (noted hereafter $\mathrm{Ln}^{+}$) are usually obtained in ICP-MS, and hereafter we only refer to this charge state.

A better understanding of the chemical reactivity of $\mathrm{Ln}^{+}$should help choosing the reacting gases in order to be able to suppress the isobaric interferences. Reactions of $\mathrm{Ln}^{+}$ions have been evidenced with several gases, ${ }^{5,11,14-21}$ suggesting that $\mathrm{Ln}^{+}$strongly reacts when it has two non-f unpaired valence electrons, and that reactivity and electronic promotion energy (PE) are correlated ${ }^{18,19}$ (PE is the energy needed for the promotion of one electron from the fundamental electronic configuration $4 \mathrm{f}^{\mathrm{n}} 5 \mathrm{~d}^{0} 6 \mathrm{~s}^{1}$ to the reactive configuration $4 \mathrm{f}^{\mathrm{n}-1} 5 \mathrm{~d}^{1} 6 \mathrm{~s}^{1}$, where $\mathrm{n}$ is the number of $4 \mathrm{f}$-electrons in the $\mathrm{Ln}^{+}$ground state). Gibson $^{22}$ also proposed a quantitative correlation between the bonding energies and the electronic promotion energies for oxide ions and molecules of the f-block elements in the gas phase.

Furthermore, chemical reactivity of metal ions is of fundamental interest for the activation of covalent bonds (typically C-H, C-C, C-O, C-F, N-H, N-O), ${ }^{5,23-28}$ and for the potential elimination of $\mathrm{H}_{2}$ associated with some of these activations, which could be used to produce gas phase $\mathrm{H}_{2}$. 
Gases with $\mathrm{O}$ donor atoms, as $\mathrm{O}_{2}$ and $\mathrm{H}_{2} \mathrm{O}$, have often been found reactive toward $\mathrm{Ln}^{+}$ions, but less selective than gases based on the softer $\mathrm{N}$ donor atoms. Namely, most $\mathrm{Ln}^{+}$ions $\left(\mathrm{La}^{+}, \mathrm{Ce}^{+}, \mathrm{Pr}^{+}, \mathrm{Nd}^{+}, \mathrm{Sm}^{+}\right.$, $\mathrm{Gd}^{+}, \mathrm{Tb}^{+}, \mathrm{Dy}^{+}, \mathrm{Ho}^{+}, \mathrm{Er}^{+}$and $\mathrm{Lu}^{+}$) are very reactive with $\mathrm{O}_{2}$ (giving $\mathrm{LnO}^{+}$) except for three of them: $\mathrm{Eu}^{+}$, $\mathrm{Tm}^{+}$and $\mathrm{Yb}^{+} .{ }^{14}$ Reactions with $\mathrm{H}_{2} \mathrm{O}$ are slightly more selective, giving $\mathrm{LnO}^{+}$with relatively high reaction rate coefficients for $\mathrm{La}^{+}, \mathrm{Ce}^{+}, \mathrm{Gd}^{+}, \mathrm{Tb}^{+}$and $\mathrm{Lu}^{+}$, and with low reaction rate coefficients for $\mathrm{Pr}^{+}$, $\mathrm{Nd}^{+}$and $\mathrm{Sm}^{+13} \cdot{ }^{13}$ donor gases such as $\mathrm{N}_{2} \mathrm{O}$ and $\mathrm{NH}_{3}$ are more selective across the $\mathrm{Ln}^{+}$series. The primary reactions with $\mathrm{N}_{2} \mathrm{O}$ generally proceed via the $\mathrm{O}$ atom transfer to the bare atomic cation for all the $\mathrm{Ln}^{+}$ions $\left(\mathrm{Ln}^{+}+\mathrm{N}_{2} \mathrm{O} \rightarrow \mathrm{LnO}^{+}+\mathrm{N}_{2}\right) .{ }^{14} \mathrm{~N}$ atom transfers leading to the $\mathrm{LnN}^{+}$cations were observed for $\mathrm{La}^{+}$and $\mathrm{Ce}^{+}\left(\mathrm{Ln}^{+}+\mathrm{N}_{2} \mathrm{O} \rightarrow \mathrm{LnN}^{+}+\mathrm{NO}\right)$. The primary reaction channel with $\mathrm{NH}_{3}$ results in the formation of the protonated lanthanoid nitride $\mathrm{LnNH}^{+}$for $\mathrm{La}^{+}, \mathrm{Ce}^{+}, \mathrm{Gd}^{+}$and $\mathrm{Tb}^{+}\left(\mathrm{Ln}^{+}+\mathrm{NH}_{3} \rightarrow \mathrm{LnNH}^{+}\right.$ $\left.+\mathrm{H}_{2}\right),{ }^{4,5}$ while $\mathrm{LnNH}^{+}$was not found for the other $\mathrm{Ln}^{+}$ions.

We presently chose to study the chemical reactivity between $\mathrm{Ln}^{+}$and $\mathrm{NH}_{3}$ gas, as $\mathrm{NH}_{3}$ appears a selective gas. As already pointed out, our present experiments are based on more energetic collisions, and the comparison between our results and the ones from Bohme and co-workers. will allow us to probe the effect of energy for the chemical reactions to occur. Another reason for that choice is that gases based on $\mathrm{N}$ donor atoms have been suggested for industrial partitioning of f-block elements, namely for selective extraction of the Am and $\mathrm{Cm}$ minor actinoids from lanthanoid fission products. ${ }^{29,30}$

Such fundamental understanding of the chemical reactivity between $\mathrm{Ln}^{+}$and $\mathrm{NH}_{3}$ gas requires associated theoretical calculations, in order to dissect more precisely the mechanisms of the chemical reactions including stable conformers formed, transition states and energetics of the reactions. Very few theoretical studies have been published on mono-cations of f-block elements in the literature. ${ }^{27,31,32}$ Very recently Ma et al. studied the insertion of $\mathrm{Ce}^{+}$in the $\mathrm{N}-\mathrm{H}$ bond of ammonia by using the DFT/B3LYP and $\operatorname{CCSD}(\mathrm{T})$ levels of calculation. ${ }^{32}$ In the present work, we will be investigating the mechanisms of the chemical reactions of $\mathrm{La}^{+}, \mathrm{Sm}^{+}, \mathrm{Eu}^{+}$and $\mathrm{Gd}^{+}$with ammonia by means of the DFT, MP2, CCSD(T) and CASSCF/CASPT2 theoretical methods. 


\section{Materials and methods.}

\subsection{Experimental set-up}

Mass spectrometry measurements were carried out with a single quadrupole ICP-MS X Series II (Thermo-Fisher Scientific, Bremen, Germany) equipped with the Collision Cell Technology (CCT). Ar plasma -in which samples are nebulized- is provided by the application of a $1250 \mathrm{~W}$ radio frequency potential at 27.12 MHz. The other main operating parameters are summarized in the Supporting Information. Spectra are recorded up to $245 \mathrm{amu}$, which corresponds to the quadrupole mass limit. Many elements can be analyzed in standard mode, i.e. without gas in the cell. Nevertheless, interferences can complicate the analysis, especially for nuclear fuels where elements are not with their natural isotopic compositions. Collision/reaction devices are currently used to get rid of such interferences. This system is based on addition of collision and/or reaction gas after cation formation. The gas impacts or reacts with an ion beam for eliminating isobaric or poly-atomic interference. The ion lens setting, the nebulizer gas-flow rate and the torch position of the instrument were optimized every day with a multi element tuning solution (SPEX) in standard mode. This solution contains $1 \mu \mathrm{g} . \mathrm{L}^{-1}$ of uranium and indium. It is used to maximize sensitivity, and to perform short term stability tests. Typical sensitivities were better than 150,000 counts. $\mathrm{s}^{-1} \cdot \mu \mathrm{g}^{-1} \mathrm{~L}$ with a residual standard deviation better than $1 \%$ for 10 measurements of 1 minute. In gas mode, a $1 \mu \mathrm{g} . \mathrm{L}^{-1}$ indium solution, which does not react with the gas, was used to maximize sensitivity for each gas flow rate.

$10 \mu \mathrm{g} . \mathrm{L}^{-1}$ Ln mono-elemental solutions were prepared from $1000 \mathrm{mg} . \mathrm{L}^{-1} \mathrm{La}$ and Eu standard SPEX, and from ${ }^{152} \mathrm{Sm}$ and ${ }^{160} \mathrm{Gd}$ mono-isotopic solutions diluted in a $0.5 \mathrm{~N}$ nitric acid solution. This $0.5 \mathrm{~N}$ nitric acid solution was prepared by diluting a sub-boiling $14.3 \mathrm{~N}$ nitric acid solution with deionized water (resistivity $18.2 \mathrm{M} \Omega \mathrm{cm}$ ). The sub-boiling nitric acid solution was obtained by distillation of a $65 \%$ $\mathrm{HNO}_{3}$ Normatom solution using an EVAPOCLEAN system (Analab, France). Indium has been added in each sample to follow the scattering losses consecutive to the introduction of a gas in the Q ICP-MS reaction cell. Ammonia (minimum purity of 99.98\%) was obtained from MESSER (Puteaux, France). High purity was used to avoid secondary reactions with impurities. Nevertheless, deuterated ammonia 
$\left(\mathrm{ND}_{3}\right)$ - D isotopic content of $99.75 \%$ - was used to check results obtained with $\mathrm{NH}_{3}$. It was purchased from Euriso-top (Gif-sur -Yvette, France). The gas flow rate was measured with a Mass Flow Controller (MFC), calibrated for He. The flow rate of $\mathrm{NH}_{3}, \varphi_{\mathrm{NH}_{3}}=\mathrm{f}_{\mathrm{NH}_{3}} \varphi_{\mathrm{He}}$, was calculated by using $\mathrm{f}_{\mathrm{NH}_{3}}=0.551$ in our conditions.

\subsection{Theoretical calculations}

Potential energy surfaces were calculated for $\mathrm{La}^{+}, \mathrm{Sm}^{+}, \mathrm{Gd}^{+}$and $\mathrm{Eu}^{+}$interacting with $\mathrm{NH}_{3}$, including minima and transition states for the relevant spin states. The geometries of the minima and the saddle points were optimized at the B3LYP level of calculation, ${ }^{33}$ while energies have been calculated at the MP2 level of theory ${ }^{34}$ and checked at higher levels of theory, typically $\operatorname{CCSD}(\mathrm{T}){ }^{35}$ The geometries of $\mathrm{LaNH}^{+}$and $\mathrm{GdNH}^{+}$were also re-optimized at the MP2 level of calculation to test the reliability of B3LYP geometries: the differences in bond distances were found to be less than $0.02 \AA$ in $\mathrm{LaNH}^{+}$and $\mathrm{GdNH}^{+}$. All these calculations were performed with the Gaussian03/09 suite of programs. ${ }^{36}$

Stuttgart's small core relativistic effective core potentials ECP28MWB ${ }^{37-39}$ with 28 core electrons were used for the Ln atoms. Note that in the ECP28MWB_SEG associated basis set, hereafter called STUT, the exponents for the g-functions were taken from f-ones. All the original f-functions were kept, while at most two g-functions with optimized exponents were found to be enough for our systems. The g-functions were found to have negligible influence on the optimized $\mathrm{Ln}-\mathrm{N}$ distance in $\mathrm{LnNH}^{+}($see Supporting Information). The STUT basis set in which the g-functions have been suppressed is called

\section{STUTf.}

STUTf was used for the B3LYP geometry optimizations, while optimized g-functions were added to STUTf for the MP2 and CCSD(T) energy calculations. The resulting basis set is here called STUTgn, where $n$ is the number of optimized g-functions $(n=1,2$ or 3$)$ : at least one g-function is needed for the MP2 energies (see Supporting Information). The STUTg2 basis set was used for the energy calculations, where the g-exponents (1.2691 and 0.4230 for La) were optimized to give the minimum MP2 energy (and in fact also giving the minimum La-N distance) for low-spin $\mathrm{LaNH}^{+}$. The original g-functions of 
the STUT basis set vary almost linearly along the Ln series; nevertheless, the same g-exponents (1.2691 and 0.4230$)$ were taken for $\mathrm{La}$ and $\mathrm{Gd}$, since linearly extrapolating the g-exponents for Gd (1.5356 and 0.5498 ) changed the energy of reaction $\mathrm{Ln}^{+}+\mathrm{NH}_{3} \rightarrow \mathrm{LnNH}^{+}+\mathrm{H}_{2}$ by less than $1 \mathrm{~kJ} . \mathrm{mol}^{-1}$. The number of g-functions has a negligible influence on the MP2 and $\operatorname{CCSD}(\mathrm{T})$ results. Finally, two identical gexponents were added on STUTf for La, Sm, Eu and Gd: they are those optimized for La (1.2691 and 0.4230). The $6-31+G(d, p)$ and the $6-311+G(2 d f, 2 p)$ basis sets for $\mathrm{N}$ and $\mathrm{H}$ atoms were used for the geometry optimizations and for the energy calculations, respectively.

Basis set superposition error (BSSE) was estimated for $\mathrm{LaNH}_{3}{ }^{+}$using the counterpoise method. ${ }^{40}$ This BSSE appeared to be small $\left(<6 \mathrm{~kJ} \cdot \mathrm{mol}^{-1}\right)$, and we did not take it into account for the final values of energies presented here. Two spin states, i.e. low spin and high spin, were considered for $\mathrm{La}^{+}(\mathrm{S}=1$ and 3), $\mathrm{Sm}^{+}(\mathrm{S}=6$ and 8$), \mathrm{Eu}^{+}(\mathrm{S}=7$ and 9$)$ and $\mathrm{Gd}^{+}(\mathrm{S}=8$ and 10). In the high spin state all the electrons are unpaired. Intrinsic reaction coordinate (IRC) $)^{41,42}$ calculations were computed for all the transition states to check the connectivity of the reactant, the transition state and the product. The zero-point energy (ZPE) was calculated at the B3LYP level. Some ZPE were calculated at the MP2 level on 11 structures along the La and Gd pathways: we found differences lower than $7 \mathrm{~kJ} . \mathrm{mol}^{-1}$ with the ZPE calculated at the B3LYP level for 10 structures. The highest difference was observed for $\mathrm{GdNH}_{3}{ }^{+}(\mathrm{S}=10)$ with a value of $12 \mathrm{~kJ} \cdot \mathrm{mol}^{-1}$. Natural population analysis (NPA) were performed with the software NBO5.9. ${ }^{43}$

The multireference character of our CCSD calculations was estimated with the T1 diagnostic: ${ }^{44}$ the values obtained for $\mathrm{LaNH}^{+}(0.013)$ and $\mathrm{GdNH}^{+}(0.023)$ indicate that the single-reference approximation is enough. To check the reliability of using single reference methods, we used CASSCF/CASPT2 method on B3LYP minimum energy geometries. The relativistic all electron ANO-RCC basis sets ${ }^{45}$ were used to validate the electronic picture given by single reference MP2, in particular, the ANO-RCCVTZP basis set was used for the Ln elements, and the ANO-RCC-VDZP basis set was used for N and $\mathrm{H}$ atoms. In all calculations, the Cholesky decomposition ${ }^{46-48}$ technique and the Douglas-Kroll-Hess Hamiltonian ${ }^{49}$ were applied to reduce the computation cost, and to account for scalar relativistic effects respectively. In order to avoid intruder states, an imaginary level shift of 0.2 a.u. was used in the 
CASPT2 calculation. ${ }^{50}$ In the cases of $\mathrm{Gd}, \mathrm{Eu}$ and $\mathrm{Sm}$, complete active spaces which include the full valence electron shells and the additional orbitals from $\mathrm{NH}_{3}$ would result in large active spaces that could not be applied in a practical fashion. Thus, a truncated version of the full valence active space was constructed by removing the empty $5 \mathrm{~d}$ orbitals of the lanthanoids out of the active space to reduce computational cost. In the case for the $\mathrm{GdNH}_{3}$ cation, we took into account 9 electrons and 9 orbitals from $\mathrm{Gd}^{+}, 3$ electrons and 3 orbitals from $\mathrm{N}, 1$ electron and 1 orbital from each $\mathrm{H}$ resulting in a 15 electron in 14 orbital active space, denoted as $(15,14)$. Similarly, a $(13,14)$ active space was applied to the $\mathrm{GdNH}^{+}$cation to ensure the consistent size of active space throughout the series for comparison purposes. Following the same approach for the choice of the active space, a $(14,14)$ and $(13,14)$ active space for the $\mathrm{EuNH}_{3}$ and $\mathrm{SmNH}_{3}$ cationic complexes respectively and other complexes' active space were adjusted as mentioned above to ensure the consistency of the size of the active space. A different active space choice was made for the La series as the La cation formally does not have any $5 \mathrm{~d}$ or $4 \mathrm{f}$ electrons. Yet to accompany possible population into the empty $5 \mathrm{~d}$ and $4 \mathrm{f}$ orbitals, we took into account 2 electrons and 4 orbitals from $\mathrm{La}^{+}$, resulting in an 8 electron in 10 orbital active space $(8,10)$ for the $\mathrm{LaNH}_{3}$ cation, other complexes' active space was adjusted accordingly by modifying the number of electrons within the active space.

The CASSCF/CASPT2 calculations were done with the MOLCAS quantum chemistry software. ${ }^{51}$

We have extended our theoretical investigations to the addition of supplementary $\mathrm{NH}_{3}$ molecules to the $\mathrm{LaNH}^{+}$, i.e. $\mathrm{LaNH}\left(\mathrm{NH}_{3}\right)_{\mathrm{n}-1}{ }^{+}+\mathrm{NH}_{3} \rightarrow \mathrm{LaNH}\left(\mathrm{NH}_{3}\right)_{\mathrm{n}}{ }^{+}$for $\mathrm{n}=1$ to 6 , using B3LYP/STUTf geometry optimizations at the low spin state $(S=1)$.

Gibbs' energy of the reaction $\left(\Delta_{\mathrm{r}} \mathrm{G}_{\mathrm{n}}{ }^{\circ}\right)$ have been calculated using MP2 electronic energies and the B3LYP harmonic thermal corrections. Superscript ${ }^{\circ}$ is for the standard state. For such reactions the thermal corrections are for the reference state conditions, ${ }^{52,53}$ especially here for the standard state pressure $\left(\mathrm{P}^{\circ}=1 \mathrm{~atm}\right)$, while $\mathrm{P}^{\text {cel }}$, the $\mathrm{NH}_{3}$ pressure in the reaction cell, is much lower (about $\left.10^{-5} \mathrm{~atm}\right)$. Negative standard Gibbs's energy of reaction $\left(\Delta_{\mathrm{r}} \mathrm{G}_{\mathrm{n}}{ }^{\circ}\right)$ typically indicates whether the $\mathrm{LnNH}\left(\mathrm{NH}_{3}\right)_{\mathrm{n}}{ }^{+}$ product is more stable than the reactants at the 1 atm reference state, while 


$$
\Delta_{\mathrm{r}} \mathrm{G}_{\mathrm{n}}{ }^{\mathrm{cel}}=\Delta_{\mathrm{r}} \mathrm{G}_{\mathrm{n}}{ }^{\circ}-\mathrm{R} \mathrm{T} \ln \left(\mathrm{P}^{\mathrm{cel}} / \mathrm{P}^{\circ}\right) .
$$

the Gibbs's energy of reaction at pressure $\mathrm{P}^{\mathrm{cel}}$, is the relevant energy change to discuss the stability of

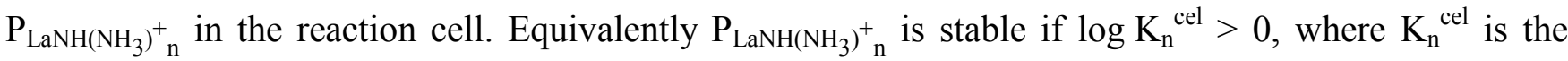
corresponding equilibrium constant. The equilibrium constants were calculated as $\Delta_{\mathrm{r}} \mathrm{G}_{\mathrm{n}}=-\mathrm{R} T \ln \mathrm{K}_{\mathrm{n}}$

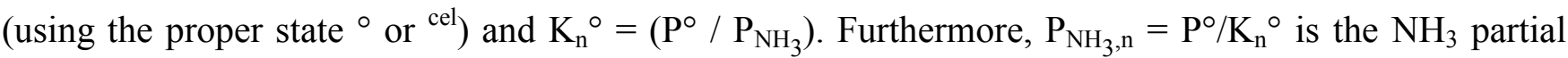
pressure at the point of half reaction, namely, $\mathrm{NH}_{3}$ partial pressure where there is the same amount of

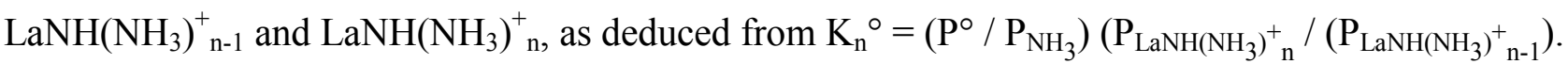

\section{Results and discussion}

We first describe our experimental results for the reaction of $\mathrm{Ln}^{+}$with $\mathrm{NH}_{3}$. They confirm the order of reactivity $\mathrm{La}^{+} \approx \mathrm{Gd}^{+}>>\mathrm{Sm}^{+}>\mathrm{Eu}^{+}$, already observed by others with different experiments. We then describe our computational results that are consistent with the difference in reactivity as observed from difference in potential energy surface (PES) and associated electronic structures through the PES.

\subsection{ICP-MS results for the $\mathrm{Ln}^{+}+\mathrm{NH}_{3}$ chemical reaction}

Results of the reactions of $\mathrm{La}^{+}, \mathrm{Sm}^{+}, \mathrm{Eu}^{+}$and $\mathrm{Gd}^{+}$in $\mathrm{NH}_{3}$ gas with our Q ICP-MS using $\mathrm{NH}_{3}$ gas at different gas flow rates in the reaction collision cell are presented in Figure 1 and 2. $\mathrm{La}^{+}$and $\mathrm{Gd}^{+}$exhibit high reactivities with $\mathrm{NH}_{3}$, giving $\mathrm{LnNH}\left(\mathrm{NH}_{3}\right)_{\mathrm{n}}{ }^{+}(\mathrm{n}=0-5)$ products (Figure 1), and their MS signals quickly decrease when $\mathrm{NH}_{3}$ is introduced (Figure 2). The major product cations seen in the spectra are $\mathrm{LaNH}^{+}$and $\mathrm{GdNH}^{+}$, representing $42 \%$ and $38 \%$ of the species, respectively $\left(\mathrm{NH}_{3}\right.$ flow rate at 0.05 ml.min ${ }^{-1}$ ), following the reaction $\mathrm{Ln}^{+}+\mathrm{NH}_{3} \rightarrow \mathrm{LnNH}^{+}+\mathrm{H}_{2} \cdot \mathrm{NH}_{3}$ can further be added to $\mathrm{LnNH}^{+}$, forming $\mathrm{LaNH}\left(\mathrm{NH}_{3}\right)_{\mathrm{n}}{ }^{+}(\mathrm{n}=1-5)$ and $\mathrm{GdNH}\left(\mathrm{NH}_{3}\right)_{\mathrm{n}}{ }^{+}(\mathrm{n}=1-4)$ complexes, as seen in the MS signatures in 
Figure 1. Complexes with more $\mathrm{NH}_{3}$ molecules could not be observed, because their masses are bigger than the mass limit of our instrument (245 amu).

Another product is observed at mass $\mathrm{M}+16$ (Fig 1). It could correspond to $\mathrm{LnNH}_{2}{ }^{+}$produced from $\mathrm{Ln}^{+}$and $\mathrm{NH}_{3}$ with H-elimination, $\mathrm{Ln}^{+}+\mathrm{NH}_{3} \rightarrow \mathrm{LnNH}_{2}^{+}+\mathrm{H}$. However, it can also be attributed to $\mathrm{LnO}^{+}$, which would arise from a possible secondary reaction with gas impurities, since $\mathrm{LnNH}_{2}^{+}$and $\mathrm{LnO}^{+}$are isobaric. To elucidate whether $\mathrm{LnNH}_{2}^{+}$was actually formed in our ICP-MS, the same experiment was repeated with deuterated ammonia $\left(\mathrm{ND}_{3}\right)$, as illustrated for $\mathrm{Gd}^{+}$in Figure 3. GdND $(\mathrm{m} / \mathrm{z}=176)$ is observed while $\mathrm{LnND}_{2}^{+}(\mathrm{m} / \mathrm{z}=178)$ is not. We therefore conclude that the peak at mass $\mathrm{M}+16$ in our $\mathrm{NH}_{3}$ spectrum of $\mathrm{La}$ and $\mathrm{Gd}$ was only due to $\mathrm{LnO}^{+} . \mathrm{NH}_{3}$ additions to $\mathrm{LnO}^{+}$to form $\mathrm{LnO}\left(\mathrm{NH}_{3}\right)_{\mathrm{n}}^{+}(\mathrm{n}=1$ to 4 or 5$)$ are also observed, as also confirmed with $\mathrm{ND}_{3}$ experiments. $\mathrm{NH}_{3}$ additions to $\mathrm{Ln}^{+}$to form $\mathrm{La}\left(\mathrm{NH}_{3}\right)_{\mathrm{n}}^{+}$( $\mathrm{n}=4$ to 6$)$ and $\mathrm{Gd}\left(\mathrm{NH}_{3}\right)_{\mathrm{n}}^{+}(\mathrm{n}=4,5)$ are also observed (Figure 1), but in relatively small quantities, i.e. $10 \%$ for both $\mathrm{La}$ and $\mathrm{Gd}\left(\mathrm{NH}_{3}\right.$ flow rate of $\left.0.05 \mathrm{~mL} \cdot \mathrm{min}^{-1}\right)$.

In contrast, $\mathrm{Eu}^{+}$reacts only slightly with $\mathrm{NH}_{3}$. We compared this signal with those obtained with not reactive indium, which signal gives the scattering loss that can explain the intensity decrease of the Eu signal (Figure 2). Only the $\mathrm{EuNH}_{3}{ }^{+}$species is detected (in very small quantities: less than $0.5 \%$ ) for the smallest value of the $\mathrm{NH}_{3}$ flow rate. The $\mathrm{EuNH}_{3}{ }^{+}$peak is no longer detected, when the $\mathrm{NH}_{3}$ flow rate is increased. This can be attributed to the decrease of the detection limit when increasing the partial pressure in the collision cell. The peak detected at the vicinity of $\mathrm{m} / \mathrm{z} 208$ is due to lead, an impurity present in the acid.

$\mathrm{Sm}^{+}$has an intermediate behavior between those of $\mathrm{La}^{+} / \mathrm{Gd}^{+}$and $\mathrm{Eu}^{+}$. The $\mathrm{Sm}^{+}$signal follows nearly the indium one, it decreases slightly more quickly with the $\mathrm{NH}_{3}$ gas flow rate (Figure 2). This reflects some affinity for ammonia. As for $\mathrm{La}$ and $\mathrm{Gd}$, a second product is also observed at mass $\mathrm{M}+16$ corresponding to $\mathrm{SmO}^{+}$as confirmed by using $\mathrm{ND}_{3}$ (Figure 1b).

Our experimental data are consistent with previous experiments, and in particular those of Koyanagi et $a l .{ }^{5}$ founding that $\mathrm{LnNH}^{+}$is a key reaction product of the reaction for several $\mathrm{Ln}$ monocations including $\mathrm{La}^{+}$and $\mathrm{Gd}^{+}$in their SIFT ICP-MS. Similarly, $\mathrm{LaNH}^{+}$and $\mathrm{GdNH}^{+}$were obtained here by using a Q ICP- 
MS. Interestingly, our results show that thermalisation of the reactants before they enter the reaction collision cell is not pivotal for the formation of $\mathrm{LaNH}^{+}$and $\mathrm{GdNH}^{+}$, as this is the main difference between the experiments performed in Ref. ${ }^{5}$ and ours. Koyanagi et $a .^{5}$ also observed the addition of up to $5 \mathrm{NH}_{3}$ molecules on $\mathrm{LaNH}^{+}$and $\mathrm{GdNH}^{+}$ions, and they did not report the formation of larger complexes.

We also demonstrated that the $\mathrm{M}+16$ peak was due to the $\mathrm{LnO}^{+}$impurity, not to isobaric $\mathrm{LnNH}_{2}^{+}$in our experimental conditions for $\mathrm{Ln}=\mathrm{La}, \mathrm{Gd}$ and $\mathrm{Sm}$, a subject debated in the literature for $\mathrm{Ce}^{+}{ }^{4,5} \mathrm{~A}$ few other $\mathrm{Ln}^{+}$cations were also studied here. Similar chemical reactivities were observed for $\mathrm{Nd}^{+}, \mathrm{Dy}^{+}$and

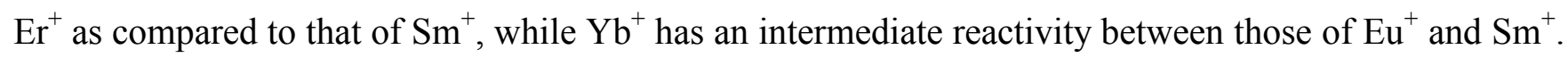
This is consistent with Koyanagi et al. results. ${ }^{5}$

\subsection{Potential Energy Surfaces for $\mathrm{Ln}^{+}+\mathrm{NH}_{3}$ reactions}

In this section, each step of the potential energy profiles (Figure 4) of the reaction pathways, and the geometries (Figure 5) are described for $\mathrm{La}^{+}, \mathrm{Gd}^{+}, \mathrm{Sm}^{+}$and $\mathrm{Eu}^{+}$reacting with one $\mathrm{NH}_{3}$ molecule. Reaction $\mathrm{LnNH}_{3}^{+} \rightarrow \mathrm{TS} 1$ will appear to be the key step to explain the differences in the reactivity across the $\mathrm{Ln}^{+}$series. The reaction mechanisms are summarized in Scheme 1.

Energies calculated at the different steps along the chemical reactions are reported in Table $\mathbf{1}$ and 2, with four different levels of representation (B3LYP, MP2, CCSD(T) and CASPT2). Energies are calculated on the B3LYP optimized geometries. Globally, each method provides similar results, with some differences that we describe in the following. In particular, B3LYP energies are in good agreement with MP2, CCSD(T) and CASPT2 methods, for almost all structures. By inspecting the T1 diagnostic of the CCSD calculations and the CASPT2 wavefunctions, it appears that only few structures display a multi-configurational character, namely $\mathrm{LaNH}_{3}{ }^{+}(\mathrm{S}=1), \mathrm{SmNH}_{3}{ }^{+}$and TS1 for $\mathrm{Sm}^{+}$reaction (both for $\mathrm{S}=6$ ), and all the Eu based compounds with $\mathrm{S}=7$ (see Supporting Information). Nevertheless, MP2 energies of these species are still reasonably close to the CASPT2 values. We can safely conclude that the MP2 method is enough in order to treat the chemical reactivity of $\mathrm{Ln}^{+}$with $\mathrm{NH}_{3}$. Note that Ma et 
$a l .{ }^{32}$ very recently studied the activation of an $\mathrm{N}-\mathrm{H}$ bond in ammonia by $\mathrm{Ce}^{+}$at the B3LYP level of theory, also finding a reasonable agreement with $\operatorname{CCSD}(\mathrm{T})$ calculations. Similarly, Matsuda et $a .^{31}$ studied C-F activation by $\mathrm{Ln}^{+}$using B3LYP and CASPT2, and showed a good agreement between the two methods.

In the following, reactivity is thus discussed on the potential energy surface (see Figure 4) calculated at the MP2 level with ZPE corrections from the B3LYP level. The discussion starts from the bare cation $\left(\mathrm{Ln}^{+}\right)$properties up to the chemical products $\left(\mathrm{LnNH}^{+}+\mathrm{H}_{2}\right)$, through intermediates $\left(\mathrm{LnNH}_{3}{ }^{+}, \mathrm{HLnNH}_{2}{ }^{+}\right)$ and transition states. Structures are shown in Figure 5.

The high spin state is the most stable one for the four bare mono-cations (Figure 4). The energy difference between $\mathrm{La}^{+}(\mathrm{S}=3)$ and $\mathrm{La}^{+}(\mathrm{S}=1)$ obtained by MP2 is $+31 \mathrm{~kJ} \mathrm{~mol}^{-1}$, reasonably close to the NIST value $\left(3 \mathrm{~kJ} \mathrm{~mol}^{-1}\right)^{54}$. The MP2 energy difference $\left(+46 \mathrm{~kJ} \mathrm{~mol}^{-1}\right)$ between $\mathrm{Gd}^{+}(\mathrm{S}=10)$ and $\mathrm{Gd}^{+}$ $(\mathrm{S}=8)$ is even closer to the NIST value $\left(35 \mathrm{~kJ}_{\mathrm{mol}}{ }^{-1}\right)^{54}$. Similarly, the MP2 energy differences between the low and the high spin of $\mathrm{Eu}^{+}\left(+20 \mathrm{~kJ} \mathrm{~mol}^{-1}\right)$ and $\mathrm{Sm}^{+}\left(+18 \mathrm{~kJ} \cdot \mathrm{mol}^{-1}\right)$ are consistent with the NIST value $\left(+20\right.$ and $+18 \mathrm{~kJ} \mathrm{~mol}^{-1}$ respectively) ${ }^{54}$ The ground states found for $\mathrm{La}^{+}$and $\mathrm{Gd}^{+}$are $[\mathrm{Xe}] 5 \mathrm{~d}^{2}$ and [Xe] $4 \mathrm{f}^{7} 5 \mathrm{~d}^{1} 6 \mathrm{~s}^{1}$ respectively, where all the valence electrons are unpaired, corresponding to the maximum possible spin multiplicity: $\mathrm{S}=3$ for $\mathrm{La}^{+}$and $\mathrm{S}=10$ for $\mathrm{Gd}^{+}$. It is in agreement with the published fundamental electronic configurations. ${ }^{5,54}$ For $\mathrm{Sm}^{+}$and $\mathrm{Eu}^{+}$, the electronic configuration are $[\mathrm{Xe}] 4 \mathrm{f}^{6} 6 \mathrm{~s}^{1}$ and $[\mathrm{Xe}] 4 \mathrm{f}^{7} 6 \mathrm{~s}^{1}$, respectively.

$\mathbf{L n}^{+}+\mathbf{N H}_{3} \rightarrow \mathbf{L n} \mathbf{N H}_{3}^{+}$. The reaction of $\mathrm{Ln}^{+}$with $\mathrm{NH}_{3}$ first proceeds through the exothermic formation of $\mathrm{LnNH}_{3}{ }^{+}$showing that the $\mathrm{La}$ and $\mathrm{Gd}$ systems are a little more exothermic $\left(\Delta_{\mathrm{r}} \mathrm{E}=-167 \mathrm{~kJ} \cdot \mathrm{mol}^{-1}\right.$ and $-153 \mathrm{~kJ} \cdot \mathrm{mol}^{-1}$, respectively) than the $\mathrm{Eu}\left(-114 \mathrm{~kJ} \cdot \mathrm{mol}^{-1}\right)$ and $\mathrm{Sm}\left(-112 \mathrm{~kJ} \cdot \mathrm{mol}^{-1}\right)$ ones. Spin multiplicity is unchanged during this step: $\mathrm{LnNH}_{3}{ }^{+}$is more stable in its high spin configuration. The optimized geometries of the $\mathrm{LnNH}_{3}{ }^{+}$complexes are $\mathrm{C}_{3 \mathrm{v}}$ (Figure 5), with virtually identical Ln-N distances for $\operatorname{Ln}=\operatorname{La}(2.61 \AA), \operatorname{Sm}(2.64 \AA), \operatorname{Eu}(2.63 \AA)$ and $\mathrm{Gd}(2.65 \AA)$. Note that low spin $\operatorname{Ln}-\mathrm{N}$ distances are shorter (Figure 5) than the corresponding high spin ones. 
$\mathrm{LnNH}_{3}{ }^{+} \rightarrow \mathrm{TS1} \rightarrow \mathrm{HLnNH}_{2}^{+}$. In the case of La and Gd, the spin multiplicity decreases in the course of the reaction. The $\mathrm{HLnNH}_{2}{ }^{+}$intermediate is more stable than the $\mathrm{LnNH}_{3}{ }^{+}$precursor. The relative energies of the reactant, the TS and the product suggest that the spin crossing occurs before reaching the transition state (TS1). The same was very recently found for $\mathrm{Ce}^{+}$in a detailed study locating the crossing points between the potential energy surfaces. ${ }^{32}$ From here, the reaction proceeds on the low spin PES for both La and Gd. The energy barrier from $\mathrm{LnNH}_{3}{ }^{+}$(high spin) to TS1 (low spin) is 105 and $155 \mathrm{~kJ}^{\mathrm{mol}}{ }^{-1}$ for La and Gd, respectively. In TS1, one $\mathrm{H}$ is bridging Ln and $\mathrm{N}$, being closer to $\mathrm{N}$ (Figure 5). Note that we did not manage to locate any TS1 for La in its high spin state $(\mathrm{S}=3)$. The low spin $\mathrm{HLnNH}_{2}{ }^{+}$ intermediate is more stable than the high spin $\mathrm{LnNH}_{3}^{+}$precursor by 100 (La) or $38 \mathrm{~kJ}^{\circ} \mathrm{mol}^{-1}(\mathrm{Gd})$. $\mathrm{HLaNH}_{2}{ }^{+}$and $\mathrm{HGdNH}_{2}{ }^{+}$in their low spin states display planar structures, while the higher energy high spin states have non-planar structures (see Fig. 5). Similar geometries were found by Mavridis et al. and by Hendrickx et al. ${ }^{55,56}$ for the reaction of $\mathrm{Sc}^{+}$with $\mathrm{NH}_{3}$. In the non-planar structures, $\mathrm{N}$ is $\mathrm{sp}^{3}$ hybridized, thus allowing the formation of only one $\sigma$ bond with $\mathrm{Ln}^{+}$, while $\mathrm{N}$ is $\mathrm{sp}^{2}$ hybridized in the planar structures, thus allowing the formation of a $\mathrm{Ln}=\mathrm{N}$ double-bond. This explains why the planar structure is stabilized: there is one more covalent bond, which is associated with electron pairing. The low spin species are more stable than the high spin ones by $244 \mathrm{~kJ} \mathrm{~mol}^{-1}$ (La) and $211 \mathrm{~kJ}^{\mathrm{m}} \mathrm{mol}^{-1}$ (Gd). $\mathrm{HLaNH}_{2}{ }^{+}$and $\mathrm{HGdNH}_{2}{ }^{+}$have very similar planar structures, where as expected the $\mathrm{Ln}=\mathrm{N}$ double bond is shorter (2.15 $\AA$ and $2.06 \AA$ for La and Gd respectively) than the single one in the $\mathrm{LnNH}_{3}{ }^{+}$reactant (2.61 $\AA$ and $2.65 \AA$ for La and Gd respectively).

In contrast, the $\mathrm{HEuNH}_{2}^{+}$intermediate is much higher in energy than the precursor $\mathrm{EuNH}_{3}^{+}$. The intermediate $\mathrm{HEuNH}_{2}{ }^{+}(\mathrm{S}=7)$ displays a multiconfigurational character (see Supporting Information). For this reason, we discuss the CASPT2 energies 
Table 2) for this reaction step of Eu. The spin multiplicity remains unchanged for the corresponding reactions of Eu: both the reactant $\left(\mathrm{EuNH}_{3}{ }^{+}\right)$and the product $\left(\mathrm{HEuNH}_{2}{ }^{+}\right)$are high spin with one unpaired electron. $\mathrm{HEuNH}_{2}{ }^{+}$is higher in energy $\left(17 \mathrm{~kJ} \mathrm{~mol}^{-1}\right.$ at the CASPT2 level of calculation) in its low spin state as compared to its high spin state. No new Eu-N covalent bond is formed. Eu-N is a single bond in both reactant $\left(\mathrm{EuNH}_{3}{ }^{+}\right)$and product $\left(\mathrm{HEuNH}_{2}{ }^{+}\right) . \mathrm{HEuNH}_{2}{ }^{+}$has a non planar structure with a Eu-N bond length $(2.39 \AA)$ longer than the La-N and Gd-N ones (2.15 $\AA$ and $2.06 \AA$, respectively). The CASPT2 energy for the reaction $\mathrm{EuNH}_{3}{ }^{+}(\mathrm{S}=9) \rightarrow \mathrm{HEuNH}_{2}{ }^{+}(\mathrm{S}=9)$ is found to be $+308 \mathrm{~kJ} . \mathrm{mol}^{-1}$. In line with the experimental observations, we propose that this energy is too high to allow the reaction to proceed. The reaction pathway is stopped because of the TS1 energy barrier to overcome.

In the case of $\mathrm{Sm}^{+}$, the $\mathrm{HSmNH}_{2}{ }^{+}$intermediate is much higher in energy than the precursor $\mathrm{SmNH}_{3}{ }^{+}$, similarly to the corresponding reaction for Eu. This was found for both the high and low spin states (Fig 4). However, $\mathrm{HSmNH}_{2}{ }^{+}$is more stable (by $161 \mathrm{~kJ} \mathrm{~mol}^{-1}$ ) in its low spin state than the high spin one, at opposite to what found in case of Eu. The energy barrier is smaller for the Sm based compound than for the Eu based one, which would predict that $\mathrm{HSmNH}_{2}{ }^{+}$could more easily formed than the $\mathrm{HEuNH}_{2}{ }^{+}$ corresponding species. The experimental reactivity of $\mathrm{Eu}^{+}$is found even smaller than that of $\mathrm{Sm}^{+}$. However, $\mathrm{SmNH}_{3}{ }^{+}$and $\mathrm{HSmNH}_{2}{ }^{+}$are isomers and thus give a single merged MS peak. The geometry of the high spin $\mathrm{HSmNH}_{2}{ }^{+}$is similar to that of $\mathrm{HEuNH}_{2}{ }^{+}$, while the geometry of the low spin $\mathrm{HSmNH}_{2}{ }^{+}$is similar to those of $\mathrm{HLaNH}_{2}{ }^{+}$and $\mathrm{HGdNH}_{2}{ }^{+}$.

Here, we pause to explain these observed differences in reactivity by taking into account the differences in promotion energies of the bare $\mathrm{Ln}^{+}$ions as suggested by Bohme and coworkers. In order to form a stable $\mathrm{Ln}=\mathrm{N}$ double bond, two non-f electrons are needed, i.e. an electronic configuration $[\mathrm{Xe}] 4 \mathrm{f}^{\mathrm{n}} 5 \mathrm{~d}^{1} 6 \mathrm{~s}^{1}$, with $\mathrm{n}=0-14$. For $\mathrm{Gd}^{+}$this is the ground state electronic configuration, thus explaining its reactivity. $\mathrm{La}^{+}$has a small promotion energy $\left(19 \mathrm{~kJ} \cdot \mathrm{mol}^{-1}\right)$ from the fundamental ground state $[\mathrm{Xe}] 4 \mathrm{f}^{0} 5 \mathrm{~d}^{2} 6 \mathrm{~s}^{0}$ to the reactive configuration $[\mathrm{Xe}] 4 \mathrm{f}^{0} 5 \mathrm{~d}^{1} 6 \mathrm{~s}^{1}$. Conversely, $\mathrm{Eu}^{+}$and $\mathrm{Sm}^{+}$are $[\mathrm{Xe}] 4 \mathrm{f}^{7} 5 \mathrm{~d}^{0} 6 \mathrm{~s}^{1}$ and $[\mathrm{Xe}] 4 \mathrm{f}^{6} 5 \mathrm{~d}^{0} 6 \mathrm{~s}^{1}$ respectively, with a promotion energy of $388 \mathrm{~kJ} \cdot \mathrm{mol}^{-1}$ and $260 \mathrm{~kJ} \cdot \mathrm{mol}^{-1}, 5$ thus explaining their high energy barrier and their lack of reactivity. 
$\boldsymbol{H L n N H}{ }_{2}^{+} \rightarrow \boldsymbol{T S} 2 \rightarrow \boldsymbol{L n N H}{ }^{+}+\boldsymbol{H}_{2}$. The following and final steps of the reaction channel are now presented for $\mathrm{La}^{+}$and $\mathrm{Gd}^{+}$in their low spin states, since the reaction path of $\mathrm{Sm}^{+}$and $\mathrm{Eu}^{+}$is stopped before the first transition step. $\mathrm{LnNH}^{+}$is formed through a four-center transition state (TS2), where $\mathrm{H}_{2}$ is weakly bound to $\mathrm{LnNH}^{+}$(Figure 5). The energy barriers from $\mathrm{HLnNH}_{2}^{+}$to $\mathrm{TS} 2$ are $63 \mathrm{~kJ}^{-\mathrm{mol}^{-1}}$ (La) and $118 \mathrm{~kJ} \cdot \mathrm{mol}^{-1}(\mathrm{Gd}) . \mathrm{LnNH}^{+}$is formed by $\mathrm{H}_{2}$ elimination from TS2. In both cases, the high spin $\mathrm{LnNH}^{+}$ structures are much higher in energy. Similar reaction pathways were proposed for $\mathrm{Sc}^{+23,24,28,57}$ and $\mathrm{Ce}^{+32}$

The $\mathrm{LaNH}^{+}$and $\mathrm{GdNH}^{+}$final products have linear structures. Their Ln-N bond lengths are the shortest ones with respect to all the other structures from the PES: $1.88\left(\mathrm{La}-N H^{+}\right)$and $1.83 \AA\left(\mathrm{Gd}_{-} \mathrm{NH}^{+}\right)($Figure 5). This is consistent with the published Sc-N (1.71 $\AA$ ) and Y-N (1.85 $\AA$ ) distances ${ }^{23,58}$ assuming similar M-N covalent bonds for $\mathrm{M}=\mathrm{Sc}, \mathrm{Y}$, La and Gd. The linear geometry of $\mathrm{LnNH}^{+}$suggests sp hybridization

for N, thus associated with Ln-N triple bond. This was confirmed in our companion paper. ${ }^{59}$ Hui-Zhen et $a l .{ }^{58}$ also found a triple bond formed in linear $\mathrm{YNH}^{+}$involving $\mathrm{Y}$ s- and d-orbitals, and $\mathrm{N}$ s- and porbitals. Note that linear structures of $\mathrm{EuNH}^{+}$and $\mathrm{SmNH}^{+}$can also be calculated, but with longer bond lengths (2.16 ̊ for both), corresponding to the formation of a double bond between $\mathrm{Ln}^{+}$and $\mathrm{NH}$.

\subsection{Adding supplementary $\mathrm{NH}_{3}$ molecules to form larger $\mathrm{LaNH}\left(\mathrm{NH}_{3}\right)_{\mathrm{n}}{ }^{+}$clusters $(\mathrm{n}=1-6)$}

The geometries of $\mathrm{LaNH}\left(\mathrm{NH}_{3}\right)_{\mathrm{n}}{ }^{+}$complexes have been optimized at the B3LYP level (

Figure 6). The $\mathrm{La} \equiv \mathrm{NH}$ bond length increases from $1.89 \AA$ for $\mathrm{n}=0$ to $2.04 \AA$ for $\mathrm{n}=6$. This bond length is much shorter than the $\mathrm{La}-\mathrm{NH}_{3}$ ones $\left(2.71\right.$ to $2.85 \AA$ ) in all the $\mathrm{LaNH}\left(\mathrm{NH}_{3}\right)_{\mathrm{n}}{ }^{+}$complexes. Shorter $\mathrm{La} \equiv \mathrm{NH}$ distance reflects that the triple bond is not much destabilized upon $\mathrm{NH}_{3}$ additions, as indeed the same type of $\mathrm{La} \equiv \mathrm{NH}$ triple bond is still present in all the $\mathrm{LaNH}\left(\mathrm{NH}_{3}\right)_{\mathrm{n}}{ }^{+}$complexes.

In $\mathrm{LaNH}\left(\mathrm{NH}_{3}\right)^{+}$, the $\mathrm{HN}-\mathrm{La}-\mathrm{NH}_{3}$ angle is almost $90^{\circ}$, while the $\left(\mathrm{HN}-\mathrm{La}-\mathrm{NH}_{3}\right)^{+}$linear isomer is a transition state, higher in energy by $40 \mathrm{~kJ} \cdot \mathrm{mol}^{-1}$. Adding up to $4 \mathrm{NH}_{3}$ molecules to the linear $\mathrm{LaNH}^{+}$ results in their placement roughly in a plane perpendicular to the $\mathrm{La} \equiv \mathrm{N}-\mathrm{H}$ axis ( 
Figure 6), so that $\mathrm{La} \equiv \mathrm{N}-\mathrm{H}$ defines a normal plane for the coordination of ligands to $\mathrm{NH}_{3}$. This geometry cannot be explained by pure electrostatic interactions, but rather it reflects constraints on angles imposed by orbitals interactions. Hence, the HOMO-3 (of essentially d-character mainly contributing to the $\sigma$ La-N covalent bond of $\mathrm{La} \equiv \mathrm{N}$ ) is anti-bonding in the para position. When adding a fifth $\mathrm{NH}_{3}$ molecule, two structures are close in energy: $\mathrm{LaNH}\left(\mathrm{NH}_{3}\right)_{5}{ }_{\text {normal }}^{+}$where all the $\mathrm{NH}_{3}$ ligands are within the normal plane (with slight distortions), or $\mathrm{LaNH}\left(\mathrm{NH}_{3}\right)_{5}{ }^{+}$para where one $\mathrm{NH}_{3}$ ligand is placed in opposition to $\mathrm{N}$ along the $\mathrm{La} \equiv \mathrm{N}$ axis. $\mathrm{LaNH}\left(\mathrm{NH}_{3}\right)_{5}{ }^{+}$normal is more stable (than $\mathrm{LaNH}\left(\mathrm{NH}_{3}\right)_{5}{ }^{+}$para ) by only $8 \mathrm{~kJ} \cdot \mathrm{mol}^{-1}$. The addition of the sixth $\mathrm{NH}_{3}$ molecule in the normal plane is prevented by steric effects. As a result, it is located in the opposite side with respect to $\mathrm{La} \equiv \mathrm{N}$, with a longer $\mathrm{La}^{-\mathrm{NH}_{3}}$ distance $(3.04 \AA)$ reflecting a weaker interaction.

$\Delta_{\mathrm{r}} \mathrm{G}_{\mathrm{n}}{ }^{\circ}$, the Gibbs energy of the reactions $\mathrm{LnNH}\left(\mathrm{NH}_{3}\right)_{\mathrm{n}-1}{ }^{+}+\mathrm{NH}_{3} \rightarrow \mathrm{LnNH}\left(\mathrm{NH}_{3}\right)_{\mathrm{n}}{ }^{+}$has been calculated, and we give an interpretation through the corresponding equilibrium constant $\mathrm{K}_{\mathrm{n}}{ }^{\circ}$ and partial pressure $\mathrm{P}_{\mathrm{NH}_{3}, \text { n }}$ of $\mathrm{NH}_{3}$ at half reaction to add an $\mathrm{n}^{\text {th }} \mathrm{NH}_{3}$ molecule to $\mathrm{LaNH}\left(\mathrm{NH}_{3}\right)_{\mathrm{n}-1}^{+}$(see Table 3 and Computational details). $\mathrm{P}_{\mathrm{NH}_{3}, \mathrm{n}}$ is found to be smaller than $\mathrm{P}_{\mathrm{NH}_{3} \text {, cel }}=10^{-5}$ atm (Table 3) for $\mathrm{n}=1$ to 5 , meaning that the $\mathrm{NH}_{3}$ pressure in the reaction-collision cell is enough to form $\mathrm{LaNH}\left(\mathrm{NH}_{3}\right)_{\mathrm{n}}{ }^{+}$up to $\mathrm{n}=5$, while $\mathrm{P}_{\mathrm{NH}_{3}, 6}>10^{-5}$ atm thus predicting that the $\mathrm{NH}_{3}$ pressure in the reaction-collision cell is too low to allow the addition of one more $\mathrm{NH}_{3}$ molecule to $\mathrm{LaNH}\left(\mathrm{NH}_{3}\right)_{5}{ }^{+}$. This thermodynamic interpretation is in line with the experimental observations of Koyanagi et al. ${ }^{5}$

\section{Conclusions}

The reactivity of $\mathrm{La}^{+}, \mathrm{Sm}^{+}, \mathrm{Eu}^{+}$and $\mathrm{Gd}^{+}$towards $\mathrm{NH}_{3}$ has been studied by coupling Q ICP-MS equipped with a collision/reaction cell experiments and the study of the associated potential energy surfaces obtained through quantum chemistry calculations.

Experimentally, two different types of reactivities were observed. $\mathrm{La}^{+}$and $\mathrm{Gd}^{+}$are very reactive and mostly give rise to $\mathrm{LnNH}^{+}$through $\mathrm{H}_{2}$ elimination. $\mathrm{Ln}^{+}$reduces $\mathrm{NH}_{3}$ into stable $\mathrm{H}_{2}$. As a result, the $\mathrm{Ln}^{+}$ 
reducer is oxidized into $\mathrm{Ln}^{\mathrm{III}}$, still assuming usual formal oxidation states in $\mathrm{LnNH}^{+}$: $\mathrm{Ln}^{\mathrm{III}}, \mathrm{N}^{-\mathrm{III}}$ and $\mathrm{H}^{\mathrm{I}}$. This type of reactions is often called in the literature activation of ammonia N-H bonds by a metallic cation, as well as insertion of metallic cation into a covalent bond. ${ }^{23,24,28} \mathrm{Up}$ to $5 \mathrm{NH}_{3}$ additions were further observed on $\mathrm{LnNH}^{+}$giving $\mathrm{LnNH}\left(\mathrm{NH}_{3}\right)_{\mathrm{n}}^{+}\left(\mathrm{n}=1\right.$ - 5). In contrast, $\mathrm{Eu}^{+}$and $\mathrm{Sm}^{+}$did not form $\mathrm{LnNH}^{+}$in our experimental conditions (about $10^{-5} \mathrm{~atm}$ of ammonia). Eu ${ }^{+}$gave less than $0.5 \%$ of $\mathrm{EuNH}_{3}{ }^{+}$, and $\mathrm{Sm}^{+}$gave about $2 \%$ of $\mathrm{SmNH}_{3}{ }^{+}\left(\right.$or $\mathrm{HSmNH}_{2}{ }^{+}$) with a gas flow rate of $0.05 \mathrm{~mL} \cdot \mathrm{min}^{-1}$. A second reaction was observed for $\mathrm{La}^{+}, \mathrm{Gd}^{+}$and $\mathrm{Sm}^{+}$leading to the formation of a monocation of mass $\mathrm{M}$ +16 , a subject debated in the literature for $\mathrm{Ce}^{+}:{ }^{4,5}$ this species does not correspond to $\mathrm{LnNH}_{2}{ }^{+}$as evidenced by using $\mathrm{ND}_{3}$, but rather to $\mathrm{LnO}^{+}$, arising from a secondary reaction with gas impurities.

Our results obtained on a commercially available Q-ICP-MS confirm the data obtained by Koyanagi et $a l .{ }^{5}$ on their SIFT-ICP-MS. These authors also pointed out that the high reactivity of $\mathrm{Ln}^{+}$is correlated with low promotion energies to electronic states that have two non-4f unpaired valence electrons. Our experimental results are consistent with such a correlation for $\mathrm{Ln}^{+}$ions with high $\left(\mathrm{La}^{+}\right.$and $\left.\mathrm{Gd}^{+}\right)$, medium $\left(\mathrm{Sm}^{+}\right)$and low $\left(\mathrm{Eu}^{+}\right)$reactivities.

Our theoretical calculations support and illustrate the key role of the Ln atomic electronic configuration. The first step of the reaction pathway is the formation of the $\mathrm{LnNH}_{3}{ }^{+}$complex for the four $\mathrm{Ln}^{+}$monocations. The second step, which leads to the formation of $\mathrm{HLnNH}_{2}^{+}$, was found the ratelimiting step. The energy barrier (TS1) for this step varies dramatically across the Ln series, well explaining in part the experimental differences in the reactivity. This transition state between $\mathrm{LnNH}_{3}{ }^{+}$ and $\mathrm{HLnNH}_{2}{ }^{+}$corresponds to one $\mathrm{H}$ transfer from $\mathrm{NH}_{3}$ to $\mathrm{Ln}$, breaking one $\mathrm{N}-\mathrm{H}$ covalent bond of $\mathrm{LnNH}_{3}{ }^{+}$, and making one new H-Ln covalent bond and one $\mathrm{Ln}=\mathrm{N}$ double bond in $\mathrm{HLnNH}_{2}{ }^{+}$. Note that the increase of the overall number of covalent bonds, increases the number of electron paires decreasing the spin multiplicity. The Ln ion must have 2 non-f electrons in order to allow the formation of the double $\mathrm{Ln}=\mathrm{N}$ covalent bond that stabilizes the $\mathrm{HLnNH}_{2}{ }^{+}$intermediate. Note that this is the key step to explain the observed differences in reactivity across the $\mathrm{Ln}^{+}$series, and the correlation with the electronic promotion energy, since the electronic promotion energy is included in the energy barrier of 
the transition state. The formation of $\mathrm{HLnNH}_{2}{ }^{+}$is exothermic for $\mathrm{La}$ and $\mathrm{Gd}$, while it is endothermic for Eu and Sm.

Cations as $\mathrm{Sm}^{+}$and $\mathrm{Eu}^{+}$have high promotion energies $\left(260 \mathrm{~kJ} \cdot \mathrm{mol}^{-1}\right.$ and $\left.388 \mathrm{~kJ} \cdot \mathrm{mol}^{-1}\right)$, which prevent them from having these 2 non-f electrons. $\mathrm{La}^{+}$has a small promotion energy $\left(19 \mathrm{~kJ}^{\mathrm{mol}}{ }^{-1}\right)$ from the fundamental electronic configuration $4 f^{0} 5 d^{2} 6 s^{0}$ to the reactive configuration $4 f^{0} 5 d^{1} 6 s^{1}$, and the energy received in the course of the $\mathrm{LaNH}_{3}{ }^{+}$formation is probably enough to allow this electronic activation. $\mathrm{Gd}^{+}$is already in the reactive configuration $4 \mathrm{f}^{7} 5 \mathrm{~d}^{1} 6 \mathrm{~s}^{1}$ in its ground state electronic configuration.

We also found that $\mathrm{LnNH}^{+}$final product is more stable for $\mathrm{La}$ and $\mathrm{Gd}$ than for $\mathrm{Eu}$ and $\mathrm{Sm}$. This is in line with the Ln-N distances that are much shorter for La (1.88 $\AA)$ and Gd (1.83 $\AA)$ than for Eu $(2.16 \AA)$ and Sm $(2.16 \AA)$, where the Ln-N bond is a triple bond for La and Gd, while it is a double bond for Sm and Eu.

Finally, our thermodynamic interpretation for the addition of $\mathrm{NH}_{3}$ to $\mathrm{LaNH}^{+}$is also consistent with ICP-MS results of Koyanagi et al. ${ }^{5}$ showing additions of no more than $5 \mathrm{NH}_{3}$ molecules. Furthermore, we found that these five $\mathrm{NH}_{3}$ ligands are coordinated in a pseudo plane normal to a linear $\mathrm{La} \equiv \mathrm{N}-\mathrm{H}^{+}$, which explains the quite small coordination number of 5 due to steric constraints. 
Table 1. Relative energies (in $\mathrm{kJ} \mathrm{mol}^{-1}$ ) obtained with different methods on the B3LYP minimum energy geometries on the La and Gd PES.

\begin{tabular}{|c|c|c|c|c|c|}
\hline System & $\mathbf{S}$ & B3LYP & MP2 & $\operatorname{CCSD}(\mathrm{T})$ & CASPT2 \\
\hline $\mathrm{La}^{+}+\mathrm{NH}_{3}$ & 1 & 54 & 31 & & 11 \\
\hline $\mathrm{La}^{+}+\mathrm{NH}_{3}$ & 3 & 0 & 0 & 0 & 0 \\
\hline $\mathrm{LaNH}_{3}^{+}$ & 1 & -127 & -174 & & -167 \\
\hline $\mathrm{LaNH}_{3}{ }^{+}$ & 3 & -161 & -152 & -160 & -169 \\
\hline TS1 La & 1 & -30 & -45 & & -8 \\
\hline $\mathrm{HLaNH}_{2}{ }^{+}$ & 1 & -254 & -250 & -250 & -255 \\
\hline $\mathrm{HLaNH}_{2}^{+}$ & 3 & 25 & 4 & & 38 \\
\hline $\mathrm{TS} 2 \mathrm{La}$ & 1 & -156 & -182 & & -133 \\
\hline $\mathrm{LaNH}^{+}+\mathrm{H}_{2}$ & 1 & -199 & -225 & -190 & -180 \\
\hline $\mathrm{LaNH}^{+}+\mathrm{H}_{2}$ & 3 & 56 & 79 & & 73 \\
\hline $\mathrm{Gd}^{+}+\mathrm{NH}_{3}$ & 8 & 25 & 46 & & 28 \\
\hline $\mathrm{Gd}^{+}+\mathrm{NH}_{3}$ & 10 & 0 & 0 & 0 & 0 \\
\hline $\mathrm{GdNH}_{3}{ }^{+}$ & 8 & -176 & -144 & & -157 \\
\hline $\mathrm{GdNH}_{3}{ }^{+}$ & 10 & -132 & -167 & - & -181 \\
\hline TS1 Gd & 8 & 7 & 21 & & -16 \\
\hline TS1 Gd & 10 & 73 & 52 & & 47 \\
\hline $\mathrm{HGdNH}_{2}{ }^{+}$ & 8 & -57 & -173 & -181 & -150 \\
\hline $\mathrm{HGdNH}_{2}{ }^{+}$ & 10 & 78 & 47 & & 42 \\
\hline $\mathrm{TS} 2 \mathrm{Gd}$ & 8 & 80 & -47 & & -67 \\
\hline $\mathrm{GdNH}^{+}+\mathrm{H}_{2}$ & 8 & 135 & -102 & -85 & -116 \\
\hline $\mathrm{GdNH}^{+}+\mathrm{H}_{2}$ & 10 & 164 & 123 & & 85 \\
\hline
\end{tabular}


Table 2. Relative energies (in $\mathrm{kJ} \mathrm{mol}^{-1}$ ) obtained with different methods on the B3LYP minimum energy geometries on the Sm and Eu PES.

\begin{tabular}{|c|c|c|c|c|}
\hline System & $\mathbf{S}$ & B3LYP & MP2 & CASPT2 \\
\hline $\mathrm{Sm}^{+}+\mathrm{NH}_{3}$ & 6 & 21 & 18 & 25 \\
\hline $\mathrm{Sm}^{+}+\mathrm{NH}_{3}$ & 8 & 0 & 0 & 0 \\
\hline $\mathrm{SmNH}_{3}{ }^{+}$ & 6 & -101 & -98 & -119 \\
\hline $\mathrm{SmNH}_{3}{ }^{+}$ & 8 & -113 & -120 & -139 \\
\hline TS1 Sm & 6 & 74 & 143 & 125 \\
\hline $\mathrm{HSmNH}_{2}{ }^{+}$ & 6 & 60 & 52 & 118 \\
\hline $\mathrm{HSmNH}_{2}{ }^{+}$ & 8 & 120 & 218 & 163 \\
\hline TS2 Sm & 6 & 123 & 41 & 160 \\
\hline $\mathrm{SmNH}^{+}+\mathrm{H}_{2}$ & 6 & 137 & 143 & 189 \\
\hline $\mathrm{SmNH}^{+}+\mathrm{H}_{2}$ & 8 & 172 & 188 & 138 \\
\hline $\mathrm{Eu}^{+}+\mathrm{NH}_{3}$ & 7 & 24 & 20 & 54 \\
\hline $\mathrm{Eu}^{+}+\mathrm{NH}_{3}$ & 9 & 0 & 0 & 0 \\
\hline $\mathrm{EuNH}_{3}^{+}$ & 7 & -79 & -97 & 86 \\
\hline $\mathrm{EuNH}_{3}{ }^{+}$ & 9 & -124 & -122 & -122 \\
\hline TS1 Eu & 7 & 132 & 225 & 164 \\
\hline TS1 Eu & 9 & 145 & 150 & 150 \\
\hline $\mathrm{HEuNH}_{2}{ }^{+}$ & 7 & 114 & 167 & 203 \\
\hline $\mathrm{HEuNH}_{2}{ }^{+}$ & 9 & 138 & 211 & 186 \\
\hline $\mathrm{TS} 2 \mathrm{Eu}$ & 7 & 192 & 213 & 149 \\
\hline TS2 Eu & 9 & 200 & 230 & 222 \\
\hline $\mathrm{EuNH}^{+}+\mathrm{H}_{2}$ & 7 & 168 & 188 & 156 \\
\hline $\mathrm{EuNH}^{+}+\mathrm{H}_{2}$ & 9 & 175 & 200 & 168 \\
\hline
\end{tabular}


Table 3. Energies (in $\mathrm{kJ} \mathrm{mol}^{-1}$ ) of reactions $\mathrm{LaNH}\left(\mathrm{NH}_{3}\right)^{+}{ }_{\mathrm{n}-1}+\mathrm{NH}_{3} \rightarrow \mathrm{LaNH}\left(\mathrm{NH}_{3}\right)^{+}$: electronic energy $\left(\Delta_{\mathrm{r}} \mathrm{E}_{\mathrm{el}, \mathrm{n}}\right), \mathrm{ZPE}$ thermal corrections at $\mathrm{T}(=298.15 \mathrm{~K})$ are included in $\Delta_{\mathrm{r}} \mathrm{E}_{\mathrm{n}} \cdot \ln \mathrm{K}_{\mathrm{n}}{ }^{\circ}\left(=-\Delta_{\mathrm{r}} \mathrm{G}_{\mathrm{n}}{ }^{\circ} / \mathrm{R}\right.$ T) for $\mathrm{P}^{\circ}(=$ $1 \mathrm{~atm})$ standard state; $\mathrm{P}_{\mathrm{NH}_{3}, \mathrm{n}}\left(=1 / \mathrm{K}_{\mathrm{n}}{ }^{\circ}\right)$ is the $\mathrm{NH}_{3}$ partial pressure at the point of half reaction. $\Delta_{\mathrm{r}} \mathrm{G}_{\mathrm{n}}{ }^{\text {cel }}(=$ $\left.\Delta_{\mathrm{r}} \mathrm{G}_{\mathrm{n}}{ }^{\circ}-\mathrm{R} \mathrm{T} \ln \mathrm{P}^{\mathrm{cel}}\right)$ is the Gibbs Energy at $\mathrm{P}^{\mathrm{cel}}$ reference state. $\mathrm{P}^{\mathrm{cel}}\left(=10^{-5} \mathrm{~atm}\right)$ is the $\mathrm{NH}_{3}$ pressure in the reaction/ collision cell.

\begin{tabular}{ccccccc}
\hline $\mathrm{n}$ & $\Delta_{\mathrm{r}} \mathrm{E}_{\mathrm{el}, \mathrm{n}}$ & $\Delta_{\mathrm{r}} \mathrm{E}_{\mathrm{n}}$ & $\Delta_{\mathrm{r}} \mathrm{G}_{\mathrm{n}}{ }^{\circ}$ & $\lg \mathrm{P}_{\mathrm{NH}_{3}, \mathrm{n}}$ & $-\operatorname{lg\mathrm {K}_{\mathrm {n}}}{ }^{\text {cel }}$ & $\Delta_{\mathrm{r}} \mathrm{G}_{\mathrm{n}}{ }^{\mathrm{cel}}$ \\
\hline 1 & -152 & -143 & -116 & -20 & -15 & -88 \\
2 & -138 & -130 & -107 & -19 & -14 & -78 \\
3 & -125 & -118 & -75 & -13 & -8 & -47 \\
4 & -102 & -95 & -60 & -10 & -5 & -31 \\
5 & -77 & -69 & -38 & -7 & -2 & -10 \\
6 & -68 & -62 & -20 & -3 & +2 & +9 \\
\hline
\end{tabular}




\section{Figures}

Figure 1. Q ICP-MS mass spectra of $10 \mu \mathrm{g} \cdot \mathrm{L}^{-1}$ solutions with $\mathrm{NH}_{3}$ reacting gas $\left(0.05 \mathrm{~mL} \cdot \mathrm{min}^{-1}\right):{ }^{139} \mathrm{La}$ standard solution (a), ${ }^{152} \mathrm{Sm}(\mathrm{b})$ and ${ }^{160} \mathrm{Gd}(\mathrm{d})$ mono-isotopic solutions, and Eu (c) standard solution.
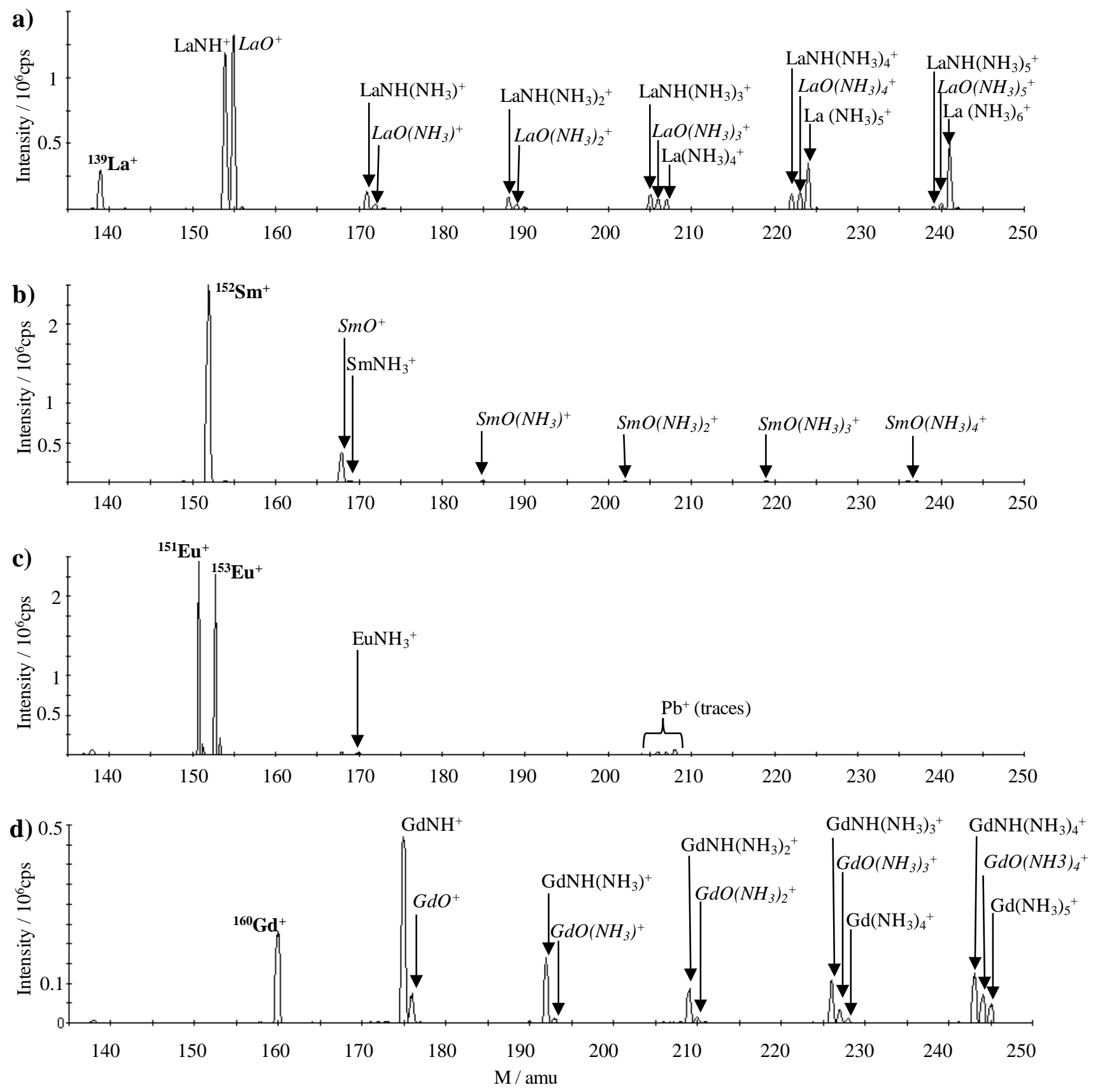
Figure 2. Influence of the $\mathrm{NH}_{3}$ flow rate in the reaction cell on the ${ }^{139} \mathrm{La}^{+}(\diamond),{ }^{152} \mathrm{Sm}^{+}(\bullet),{ }^{151} \mathrm{Eu}^{+}()$and ${ }^{160} \mathrm{Gd}^{+}(\Delta)$ Q ICP-MS signals. The $\mathrm{Ln}^{+}$signals are compared to the ${ }^{115} \operatorname{In}^{+}(\boldsymbol{\square})$ one, which is non-reactive with $\mathrm{NH}_{3}$.

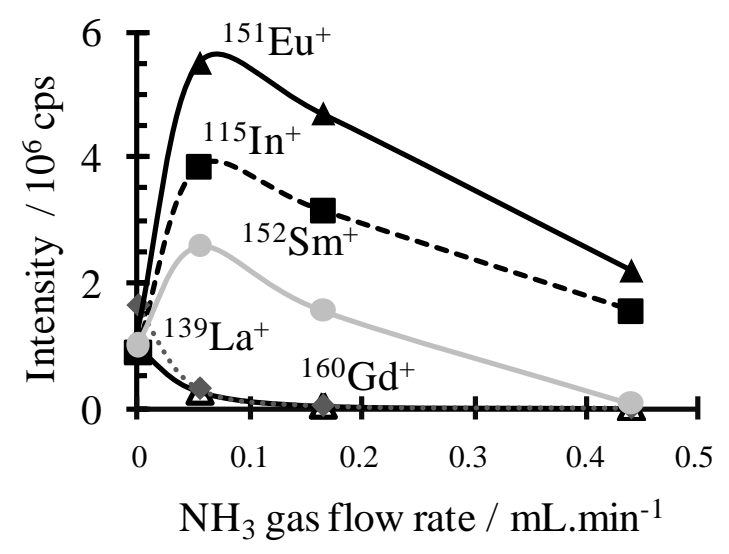

Figure 3. Mass spectra of a $10 \mu \mathrm{g} . \mathrm{L}^{-1}{ }^{160} \mathrm{Gd}$ mono-isotopic solution with $\mathrm{NH}_{3}$ (a) or $\mathrm{ND}_{3}$ (b) reacting gas $\left(0.05 \mathrm{~mL} \cdot \mathrm{min}^{-1}\right)$.
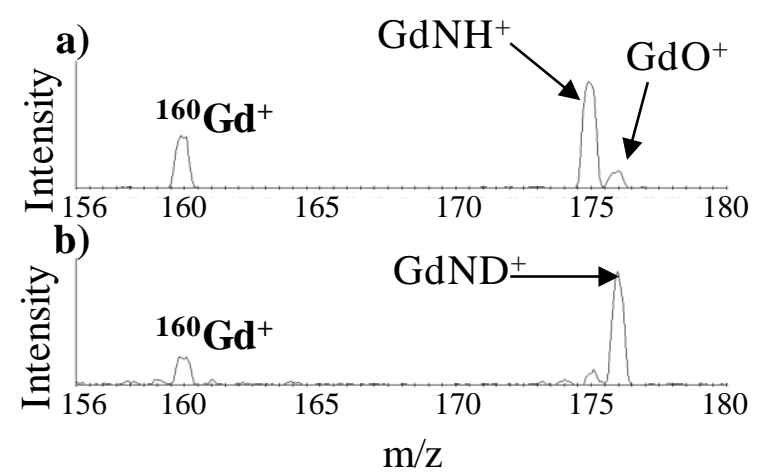
Figure 4. Energy profiles for reactions of $\mathrm{NH}_{3}$ on $\mathrm{Ln}^{+}$in low (-) and high (---) spin multiplicities relative to $\mathrm{Ln}^{+}$(High spin) $+\mathrm{NH}_{3}$, including ZPE calculated at the B3LYP level.

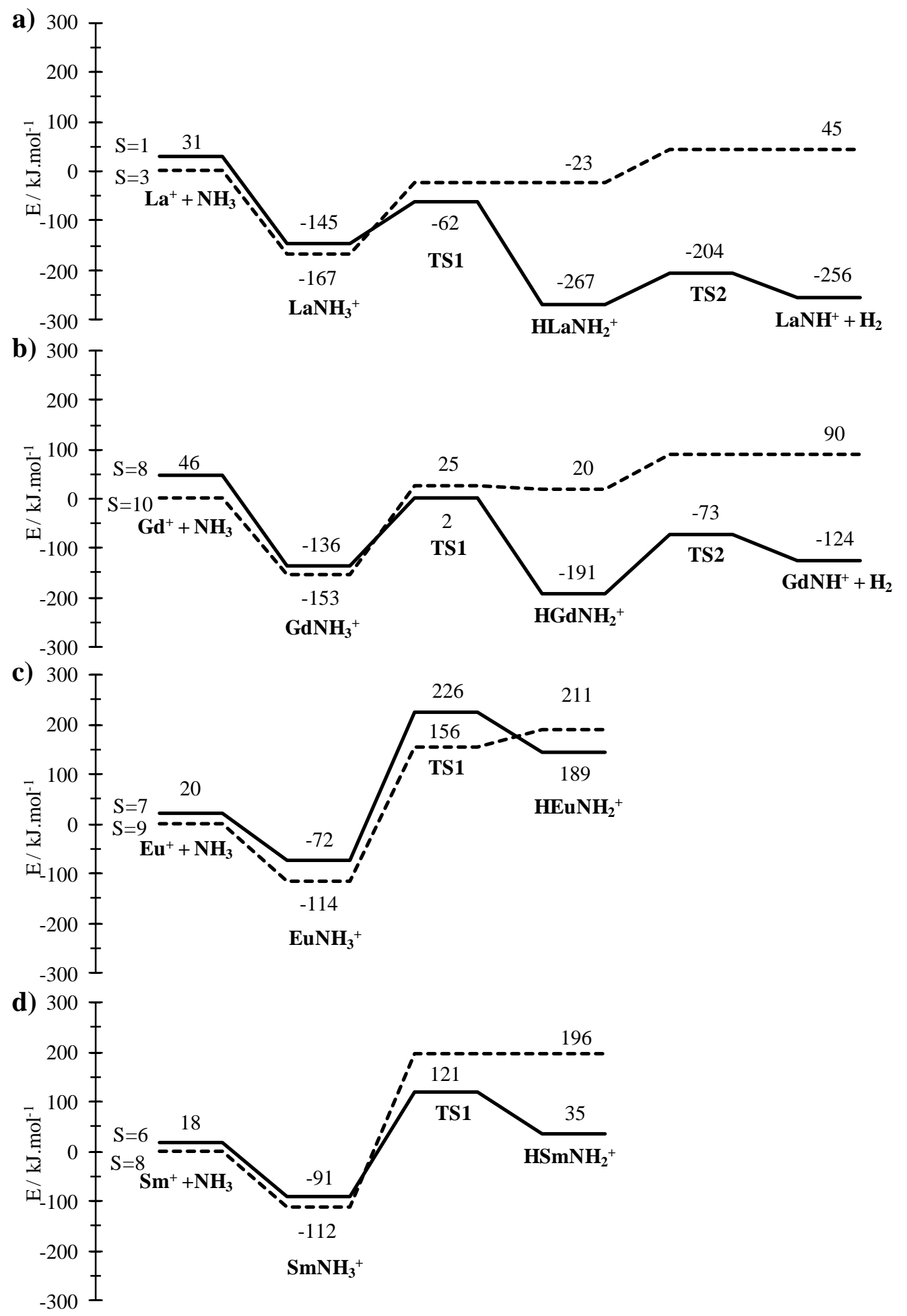


Figure 5. Geometries of all structures explored in the PES. The bond lengths are in angstroms, and the angles are in degrees.

a) $L a S=1$

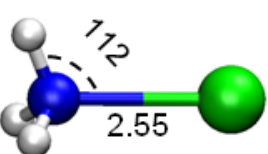

$\mathrm{LaNH}_{3}{ }^{+}$

b) La $S=3$

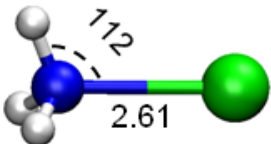

$\mathrm{LaNH}_{3}{ }^{+}$

c) $\mathrm{Gd} \mathrm{S}=8$

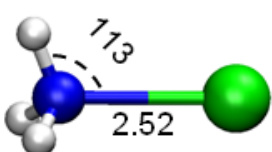

$\mathrm{GdNH}_{3}^{+}$

d) $\mathrm{Gd} \mathrm{S}=10$

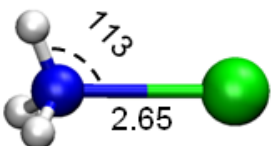

$\mathrm{GdNH}_{3}{ }^{+}$

e) Eu $S=7(S=9)$

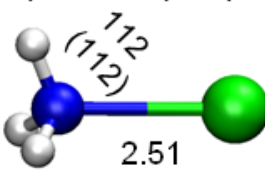

(2.63)

$\mathrm{EuNH}_{3}{ }^{+}$

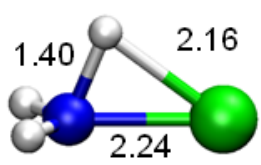

TS1

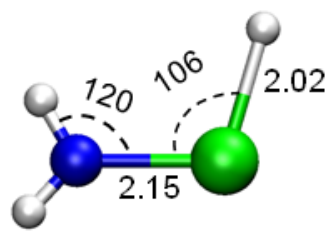

$\mathrm{HLaNH}_{2}{ }^{+}$

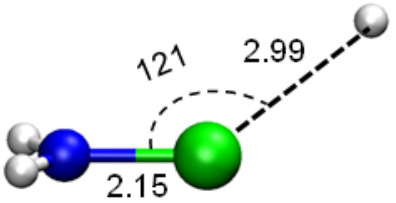

TS1

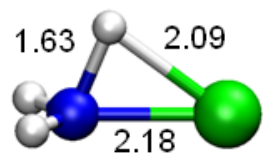

TS1

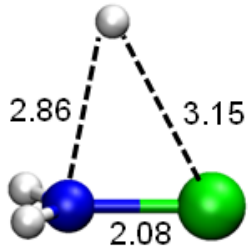

TS1

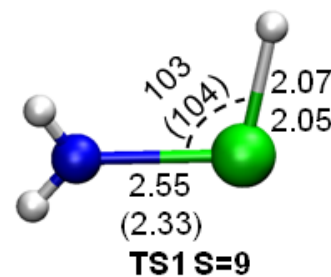

$\mathrm{HLaNH}_{2}{ }^{+}$

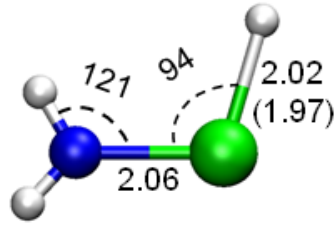

$\mathrm{HGdNH}_{2}{ }^{+}$

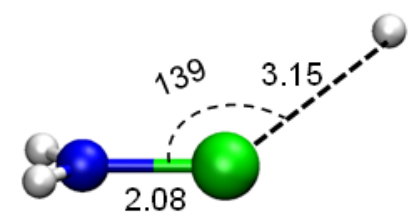

$\mathrm{HGdNH}_{2}{ }^{+}$

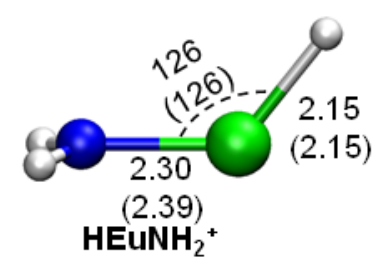

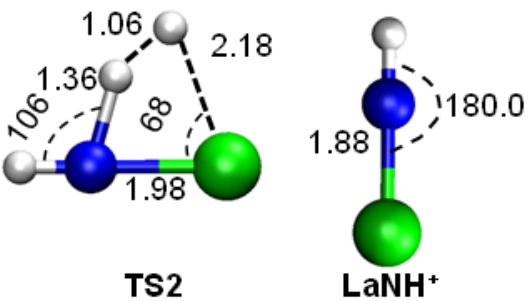
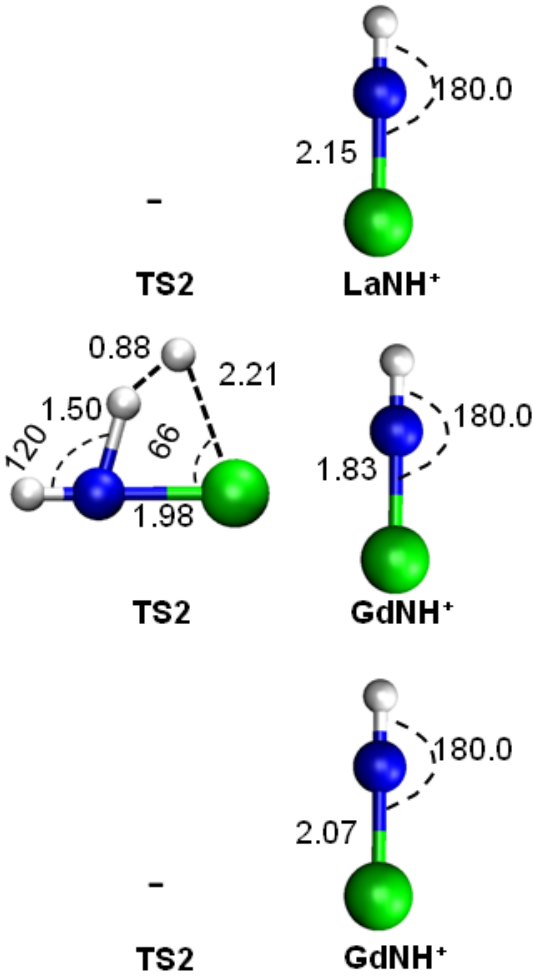

f) $\mathrm{Sm} \mathrm{S}=6(\mathrm{~S}=8)$

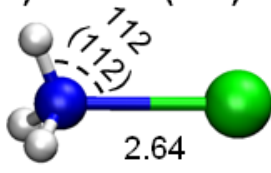

(2.64)

$\mathrm{SmNH}_{3}{ }^{+}$

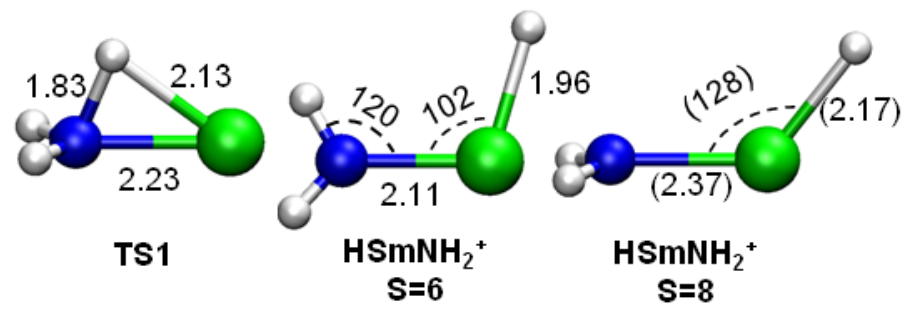


Figure 6. Optimized structures of $\mathrm{LaNH}\left(\mathrm{NH}_{3}\right)_{\mathrm{n}}{ }^{+}$complexes. The bond lengths are in angstroms and the angles are in degrees.
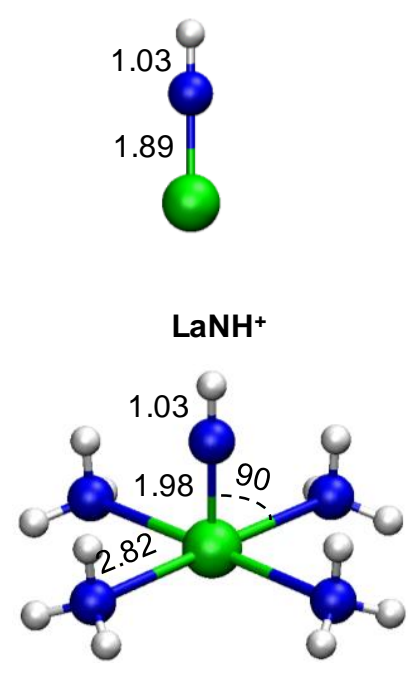

$\operatorname{LaNH}\left(\mathrm{NH}_{3}\right)_{4}{ }^{+}$

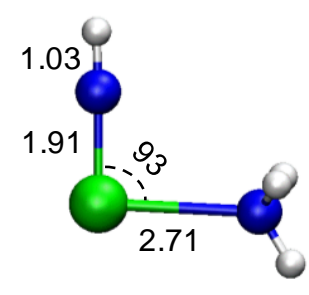

$\operatorname{LaNH}\left(\mathrm{NH}_{3}\right)^{+}$

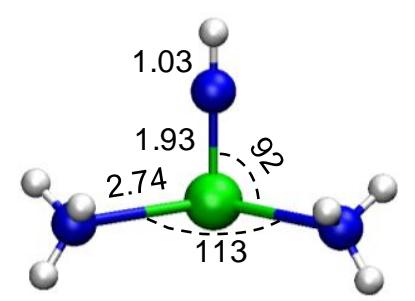

$\operatorname{LaNH}\left(\mathrm{NH}_{3}\right)_{2}{ }^{+}$
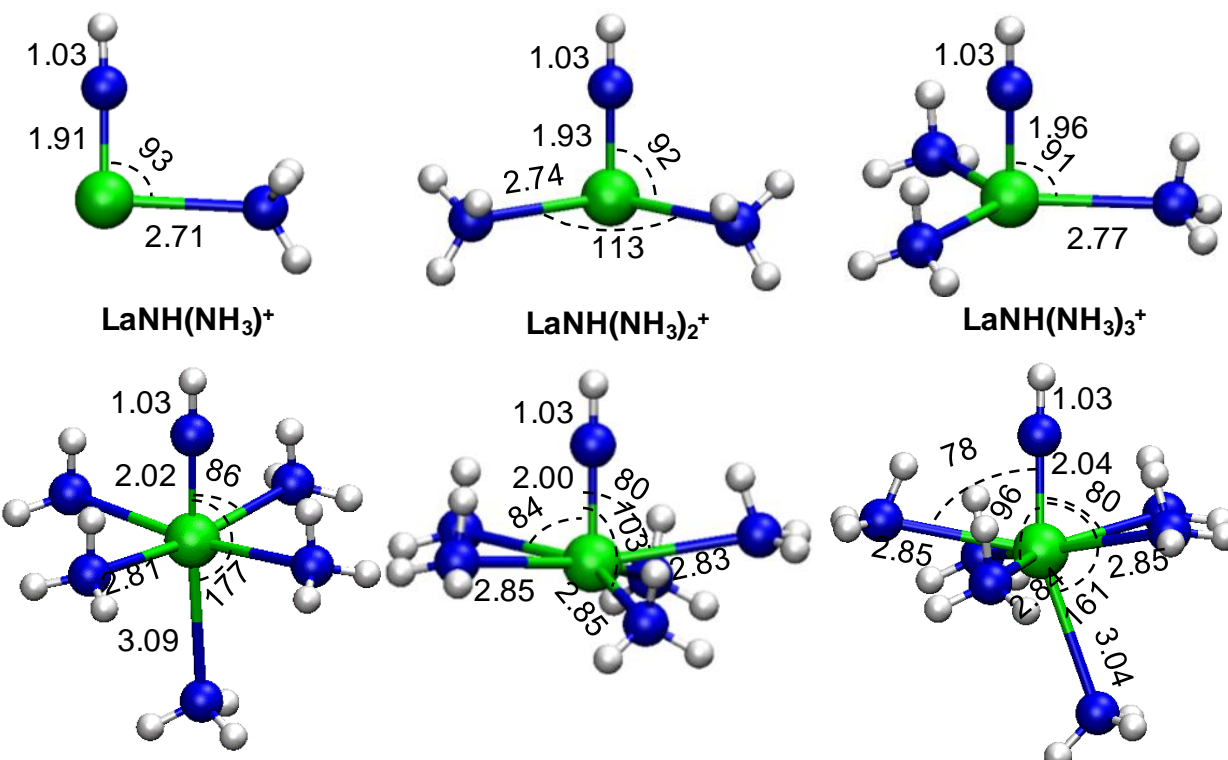

$\mathrm{LaNH}\left(\mathrm{NH}_{3}\right)_{5}{ }^{+}$para

$\operatorname{LaNH}\left(\mathrm{NH}_{3}\right)_{5}{ }^{+}$normal

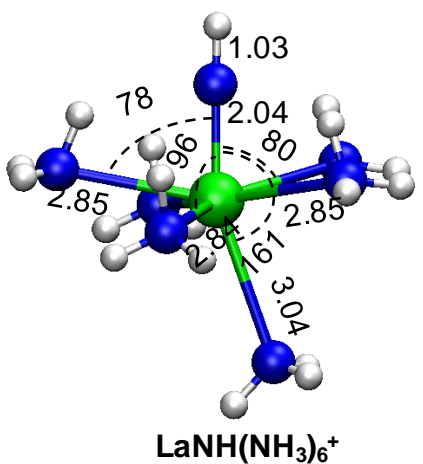


Scheme 1. Schema of reaction $\mathrm{Ln}^{+}+\mathrm{NH}_{3} \rightarrow \mathrm{LnNH}^{+}+\mathrm{H}_{2}$ for $\mathrm{La}$ and $\mathrm{Gd}$ (a), and for Eu and Sm (b). Transition states are in [ ]. The $\operatorname{dot}(\bullet)$ represent a valence electron. Dotted arrows represent endothermic reactions.

a) $\mathrm{La}^{+}$and $\mathrm{Gd}^{+}$

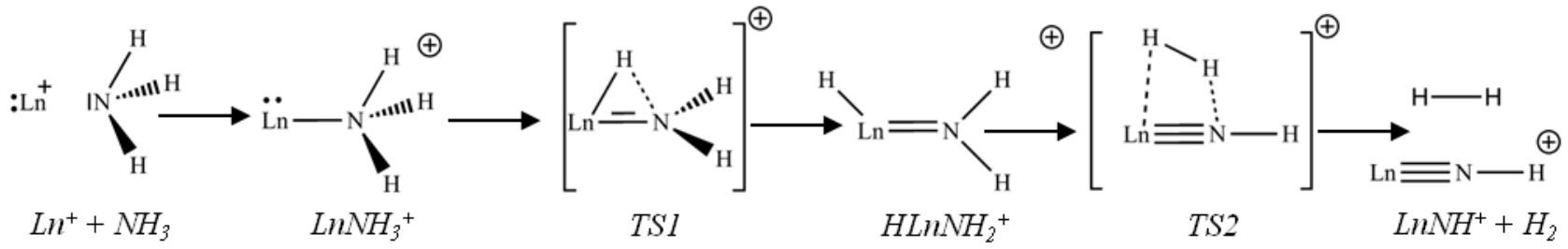

b) $\mathrm{Eu}^{+}$and $\mathrm{Sm}^{+}$

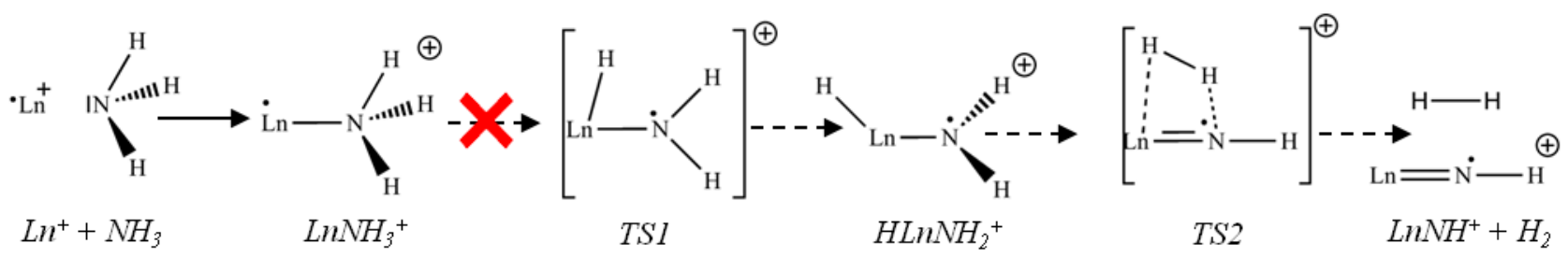




\section{References}

(1) Kim, C. S.; Kim, C. K.; Martin, P.; Sansone, U. Journal of Analytical Atomic Spectrometry 2007, 22, 827.

(2) Huntley, M. W. Radiochimica Acta 2001, 89, 605.

(3) Alonso, J. I. G.; Sena, F.; Arbore, P.; Betti, M.; Koch, L. Journal of Analytical Atomic Spectrometry 1995, 10, 381.

(4) Tanner, S. D.; Baranov, V. I.; Bandura, D. R. Spectrochimica Acta Part B-Atomic Spectroscopy 2002, 57, 1361.

241.

(5) Koyanagi, G. K.; Cheng, P.; Bohme, D. K. Journal of Physical Chemistry A 2010, 114,

(6) Bacon, J. R.; Crain, J. S.; Van Vaeck, L.; Williams, J. G. Journal of Analytical Atomic Spectrometry 2001, 16, 879.

(7) Eiden, G. C.; Barinaga, C. J.; Koppenaal, D. W. Rapid Communications in Mass Spectrometry 1997, 11, 37.

(8) Olesik, J. W.; Jones, D. R. Journal of Analytical Atomic Spectrometry 2006, $21,141$.

(9) Brennetot, R.; Stadelmann, G.; Caussignac, C.; Gombert, C.; Fouque, M.; Lamouroux, C. Talanta 2009, 78, 676.

(10) Gourgiotis, A.; Granet, M.; Isnard, H.; Nonell, A.; Gautier, C.; Stadelmann, G.; Aubert, M.; Durand, D.; Legand, S.; Chartier, F. Journal of Analytical Atomic Spectrometry 2010, 25, 1939.

(11) Blagojevic, V.; Flaim, E.; Jarvis, M. J. Y.; Koyanagi, G. K.; Bohme, D. K. International Journal of Mass Spectrometry 2006, 249, 385.

2718.

(12) Cheng, P.; Koyanagi, G. K.; Bohme, D. K. Journal of Physical Chemistry A 2006, 110,

(13) Cheng, P.; Koyanagi, G. K.; Bohme, D. K. Chemphyschem 2006, 7, 1813.

(14) Koyanagi, G. K.; Bohme, D. K. Journal of Physical Chemistry A 2001, 105, 8964.

(15) Shayesteh, A.; Lavrov, V. V.; Koyanagi, G. K.; Bohme, D. K. Journal of Physical Chemistry A 2009, 113, 5602.

(16) Cheng, P.; Bohme, D. K. Inorganic Chemistry 2006, 45, 7856.

(17) Cheng, P.; Koyanagi, G. K.; Bohme, D. K. Journal of Physical Chemistry A 2006, 110, 12832.

(18) Schilling, J. B.; Beauchamp, J. L. Journal of the American Chemical Society 1988, 110, 15.

(19) Cornehl, H. H.; Heinemann, C.; Schroder, D.; Schwarz, H. Organometallics 1995, 14, 992.

(20) Gibson, J. K. Journal of Physical Chemistry 1996, 100, 15688.

(21) Carretas, J. A.; Marcalo, J.; de Matos, A. P. International Journal of Mass Spectrometry 2004, 234, 51.

(22) Gibson, J. K. Journal of Physical Chemistry A 2003, 107, 7891.

(23) Russo, N.; Sicilia, E. Journal of the American Chemical Society 2001, 123, 2588.

(24) Nakao, Y.; Taketsugu, T.; Hirao, K. Journal of Chemical Physics 1999, 110, 10863.

(25) Cornehl, H. H.; Hornung, G.; Schwarz, H. Journal of the American Chemical Society 1996, $118,9960$.

(26) Carretas, J. M.; de Matos, A. P.; Marcalo, J. Journal of the American Society for Mass Spectrometry 1998, 9, 1035.

(27) Liu, H. W.; Wang, Y. C.; Geng, Z. Y.; Lv, L. L.; Yan, B.; Wang, Q.; Cui, D. D. Journal of Molecular Structure-Theochem 2010, 944, 89.

(28) Kretschmer, R.; Schlangen, M.; Schwarz, H. Chemistry-a European Journal 2012, 18, 40.

(29) Musikas, C.; Cuillerdier, C.; Livet, J.; Forchioni, A.; Chachaty, C. Inorganic Chemistry $1983,22,2513$. 
(30) Bhattacharyya, A.; Ghanty, T. K.; Mohapatra, P. K.; Manchanda, V. K. Inorganic Chemistry 2011, 50, 3913.

(31) Matsuda, A.; Mori, H. Chemical Physics 2011, 380, 48.

(32) Ma, W. P.; Wang, Y. C.; Lv, L. L.; Jin, Y. Z.; Nian, J. Y.; Ji, D. F.; Wang, C. L.; La, M. J.; Wang, X. B.; Wang, Q. Computational and Theoretical Chemistry 2011, 977, 69.

(33) Becke, A. D. Journal of Chemical Physics 1993, 98, 5648.

(34) Møller, C.; Plesset, M. S. Physical review 1934, 46, 618.

(35) Pople, J. A.; Headgordon, M.; Raghavachari, K. Journal of Chemical Physics 1987, 87, 5968.

(36) Frisch, M. J.; Trucks, G. W.; Schlegel, H. B.; Scuseria, G. E.; Robb, M. A.; Cheeseman, J. R.; Scalmani, G.; Barone, V.; Mennucci, B.; Petersson, G. A.; Nakatsuji, H.; Caricato, M.; Li, X.; Hratchian, H. P.; Izmaylov, A. F.; Bloino, J.; Zheng, G.; Sonnenberg, J. L.; Hada, M.; Ehara, M.; Toyota, K.; Fukuda, R.; Hasegawa, J.; Ishida, M.; Nakajima, T.; Honda, Y.; Kitao, O.; Nakai, H.; Vreven, T.; Montgomery, J., J. A.; Peralta, J. E.; Ogliaro, F.; Bearpark, M.; Heyd, J. J.; Brothers, E.; Kudin, K. N.; Staroverov, V. N.; Kobayashi, R.; Normand, J.; Raghavachari, K.; Rendell, A.; Burant, J. C.; Iyengar, S. S.; Tomasi, J.; Cossi, M.; Rega, N.; Millam, N. J.; Klene, M.; Knox, J. E.; Cross, J. B.; Bakken, V.; Adamo, C.; Jaramillo, J.; Gomperts, R.; Stratmann, R. E.; Yazyev, O.; Austin, A. J.; Cammi, R.; Pomelli, C.; Ochterski, J. W.; Martin, R. L.; Morokuma, K.; Zakrzewski, V. G.; Voth, G. A.; Salvador, P.; Dannenberg, J. J.; Dapprich, S.; Daniels, A. D.; Farkas, Ö.; Foresman, J. B.; Ortiz, J. V.; Cioslowski, J.; Fox, D. J. Gaussian 09, Revision B.01 Gaussian 09, Revision B.01, Gaussian, Inc., Wallingford CT, 2010., 2010.

(37) Cao, X. Y.; Dolg, M. Journal of Chemical Physics 2001, 115, 7348.

(38) Cao, X. Y.; Dolg, M. Journal of Molecular Structure-Theochem 2002, 581, 139.

(39) Dolg, M.; Stoll, H.; Preuss, H. Theoretica Chimica Acta 1993, 85, 441.

(40) Boys, S. F.; Bernardi, F. Molecular Physics 1970, 19, 553.

(41) Gonzalez, C.; Schlegel, H. B. Journal of Chemical Physics 1989, 90, 2154.

(42) Truhlar, D. G.; Gordon, M. S. Science 1990, 249, 491.

(43) NBO5.9; Glendening, E. D.; Badenhoop, J. K.; Reed, A. E.; Carpenter, J. E.; Bohmann, J. A.; Morales, C. M.; Weinhold, F.; (Theoretical Chemistry Institute, U. o. W., Madison, WI, 2009); http://www.chem.wisc.edu/ nbo5.

(44) Lee, T. J.; Taylor, P. R. International Journal of Quantum Chemistry 1989, 199.

(45) Roos, B. O.; Lindh, R.; Malmqvist, P. A.; Veryazov, V.; Widmark, P. O. Journal of Physical Chemistry A 2005, 109, 6575.

(46) Aquilante, F.; Gagliardi, L.; Pedersen, T. B.; Lindh, R. Journal of Chemical Physics 2009, 130.

(47) Aquilante, F.; Pedersen, T. B.; Lindh, R. Journal of Chemical Physics 2007, 126.

(48) Aquilante, F.; Pedersen, T. B.; Lindh, R.; Roos, B. O.; De Meras, A. S.; Koch, H. Journal of Chemical Physics 2008, 129.

(49) Hess, B. A. Physical Review A 1986, 33, 3742.

(50) Forsberg, N.; Malmqvist, P. A. Chemical Physics Letters 1997, 274, 196.

(51) Aquilante, F.; De Vico, L.; Ferre, N.; Ghigo, G.; Malmqvist, P.-A.; Neogrady, P. 1.; Pedersen, T. B.; Pitonak, M.; Reiher, M.; Roos, B. O.; Serrano-Andres, L.; Urban, M.; Veryazov, V.; Lindh, R. Journal of Computational Chemistry 2010, 31, 224.

(52) Zhou, H. X.; Gilson, M. K. Chemical Reviews 2009, 109, 4092.

(53) Stokes, R. H. Activity Coefficients in Electrolyte Solutions; nd edn, K. P. e., Crc Press: Boca Raton, F., Eds., 1991.

(54) Nist. Nist atomic spectra database (3.1.5), http://webbook.nist.gov, 2010.

(55) Mavridis, A.; Herrera, F. L.; Harrison, J. F. Journal of Physical Chemistry 1991, 95, 6854.

(56) Hendrickx, M. F. A.; Clima, S. Journal of Physical Chemistry A 2006, 110, 12629. 
(57) Clemmer, D. E.; Sunderlin, L. S.; Armentrout, P. B. Journal of Physical Chemistry 1990, 94, 3008 .

(58) Hui-Zhen, L.; Yong-Cheng, W.; Zhi-Yuan, G.; Qing-Li, Z.; Qing-Yun, W.; Yu-Bing, S. Journal of Molecular Structure: THEOCHEM 2008, 866, 5.

(59) Quemet, A.; Brennetot, R.; Salpin, J. Y.; Cimas, A.; Marsden, C. J.; Tortajada, J.; Vitorge, P. European Journal of Inorganic Chemistry 2012, accepted 
TOC

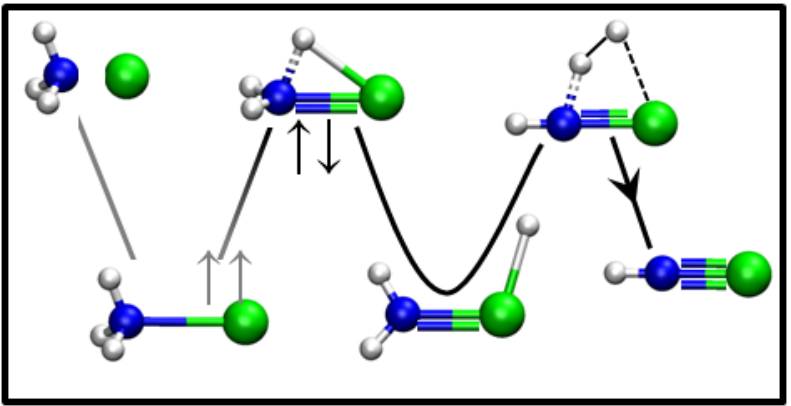

N-H bond activation of $\mathrm{NH}_{3}$ by $\mathrm{La}^{+}$or $\mathrm{Gd}^{+}$, double vertical arrows illustrate spin crossing. 